\title{
THE PROBLEMATIZATION OF ASYLUM SEEKERS A CRITICAL DISCOURSE ANALYSIS OF CANADIAN NATIONAL NEWS MEDIA COVERAGE
}

\author{
by \\ Melissa Yu Vanti \\ BA Hons, University of Toronto at Scarborough, 2008 \\ A Major Research Project \\ presented to Ryerson University \\ in partial fulfillment of the requirements for the degree of \\ Master of Arts \\ in the Program of Immigration and Settlement Studies
}

Toronto, Ontario, Canada, 2019

(C) Melissa Yu Vanti 2019 


\section{AUTHOR'S DECLARATION FOR ELECTRONIC SUBMISSION OF A MAJOR RESEARCH PROJECT}

I hereby declare that I am the sole author of this Major research project. This is a true copy of the MRP, including any required final revisions, as accepted by my examiners.

I authorize Ryerson University to lend this MRP to other institutions or individuals for the purpose of scholarly research.

I further authorize Ryerson University to reproduce this MRP by photocopying or by other means, in total or in part, at the request of other institutions or individuals for the purpose of scholarly research.

I understand that my MRP may be made electronically available to the public. 


\title{
THE PROBLEMATIZATION OF ASYLUM SEEKERS \\ A CRITICAL DISCOURSE ANALYSIS \\ OF CANADIAN NATIONAL NEWS MEDIA COVERAGE
}

\author{
Melissa Yu Vanti \\ Master of Arts 2019 \\ Immigration and Settlement Studies \\ Ryerson University
}

\begin{abstract}
Using the methodology of critical discourse analysis, this research project analysed 70 news media articles from the Globe and Mail and the National Post on the topic of asylum seekers who crossed into Canada from the U.S. between ports of entry in 2017 and 2018. Analysis revealed that asylum seekers were largely depicted, portrayed, and framed in problematizing ways, leading to their dehumanization and a decontextualization of the larger issues.
\end{abstract}

Keywords: Asylum seekers; refugees; news media coverage; critical discourse analysis 


\section{Acknowledgements}

To Dr. Myer Siemiatycki: Thank you for committing your valuable time and energy towards this research as my supervisor. I am grateful for the clear direction and thoughtful critiques you provided throughout the process. Your generosity and thoughtful approach to teaching is both supportive and motivating, and empowered me to do my best. I am eternally proud of what I have been able to produce and thank you for your guidance. It has been an honour and privilege to learn from you in your last two years at Ryerson.

To Dr. Anver Saloojee: Thank you for contributing as my second reader and for the delightful discussion. Your inquiry and curiosity always teaches, always pushes, always motivates me to think past what is presented on the page. 


\section{Dedication}

To my father: Thank you for being the inspiration for me to break traditional conventions of Chinese culture. From this I have been able to forge my own version of "Chineseness" in the context of being a racialized woman in the twenty-first century in this white settler nation now called Canada. You motivated me to examine more deeply my place as a second-generation Canadian and the immigration pathway that led our family to Toronto.

To my mother: Thank you for the way you love and your unwavering and constant support. Your acts of feminist resistance in a world steeped in patriarchy have not gone unnoticed. You led by example as the first in our family to obtain both an undergraduate and graduate degree and inspired me to do the same.

To the soon-to-be Dr. Maya Kalogirou: Thank you for your invaluable and ever-patient, ever-loving guidance, teaching, and coaching from the first to the last moment. A future generation of nurses are incredibly lucky that they will have you as a teacher and mentor. I am eternally grateful for your friendship.

To Alan Vanti: Thank you for everything in between. Thank you for holding our beautiful life together with grace and humour these past two years. This is for us; this is for our family. 


\section{Table of Contents}

$\begin{array}{ll}\text { Author's Declaration } & \text { ii }\end{array}$

$\begin{array}{ll}\text { Abstract } & \text { iii }\end{array}$

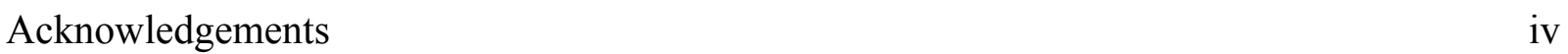

Dedication $\quad$ V

Introduction: This Research Project $\quad 1$

$\begin{array}{ll}\text { Context } & 6\end{array}$

$\begin{array}{ll}\text { Key Terms and Definitions } & 6\end{array}$

$\begin{array}{ll}\text { The Global Context of Forced Migration } & 7\end{array}$

The Role of News Media $\quad 9$

Trump's Anti-Immigration Stance and Trudeau's Response $\quad 10$

Canada-United States Safe Third Country Agreement 13

Existing Scholarly Research on News Media Framing of Migrants 15

Methodology of Critical Discourse Analysis $\quad 20$

Data Collection and Inclusion $\quad 23$

The Globe and Mail. $\quad 24$

The National Post. $\quad 25$

$\begin{array}{ll}\text { Random Sampling. } & 27\end{array}$

$\begin{array}{ll}\text { Analysis of News Media Articles } & 27\end{array}$

Asylum Seekers: "Takers Rather than Givers" 28 
The "Us” Versus “Them” Division 30

Dehumanization 33

Compromised Canadian Systems 37

Limitations of the Global Immigration Regime 39

Individualization, Personalization, and Perspective 42

Idealized and Inclusive Canada $\quad 45$

$\begin{array}{ll}\text { Limitations } & 46\end{array}$

$\begin{array}{ll}\text { Discussion and Implications } & 47\end{array}$

Recommendations for Future Research $\quad 54$

$\begin{array}{ll}\text { Conclusion } & 55\end{array}$

Appendix A: Data Set $\quad 66$

$\begin{array}{ll}\text { The Globe and Mail } & 66\end{array}$

Editorial Articles. $\quad 66$

News Articles. $\quad 66$

$\begin{array}{ll}\text { Opinion Articles. } & 69\end{array}$

$\begin{array}{ll}\text { The National Post } & 70\end{array}$

$\begin{array}{ll}\text { Editorial Articles. } & 70\end{array}$

$\begin{array}{ll}\text { News Articles. } & 70\end{array}$

$\begin{array}{ll}\text { Opinion Articles. } & 72\end{array}$

Appendix B: Data Extraction Questions $\quad 74$

$\begin{array}{ll}\text { References } & 56\end{array}$ 


\section{CHAPTER 1}

\section{Introduction: This Research Project}

Now more than ever, people around the world are on the move, displaced and forced to migrate because their home communities have become uninhabitable and unsafe. The United Nations High Commissioner for Refugees (UNHCR) (2019b) reported that in 2018, over 70.8 million people were displaced worldwide, a 2.3 million increase from 2017. Many of these individuals have been caught in the crosshairs of war, violence, and/or persecution, forced from their homes in search of better living conditions and opportunities for themselves and their families. These are complicated and challenging situations that people do not choose for themselves (Behrman, 2014). Once they have left their homes, they must find a place for refuge, which can translate to them being displaced for weeks, years, and in some cases, an indefinite amount of time away. During that time, they are likely to weigh any and all options available to them: to stay where they have found temporary refuge, return home (potentially to the same threats that forced them to leave), or to make efforts to resettle elsewhere.

In 2017 and 2018, there were approximately 105,400 individuals who claimed asylum in Canada, processed either by the Canada Border Services Agency (CBSA) or Immigration, Refugees, and Citizenship Canada (IRCC) (Government of Canada, 2019a; Government of Canada, 2019b). These asylum claims were made by people through one of three main avenues: an official air, land, or marine port of entry, a CBSA inland office, or an IRCC inland office (Government of Canada, 2019a; Government of Canada, 2019b). Approximately 40,000 or 38 per cent of the total number of claims over this two-year period were from asylum seekers who were intercepted between ports of entry (referred to by the Canadian government as 
irregular migrants) (Government of Canada, 2019a; Government of Canada, 2019b; Statistics

Canada, 2019). The number of those who crossed in 2017 and 2018 were over double the amount who did so in 2016 and the highest since the year 2000 (Statistics Canada, 2019). This research project is focused on this particular group of asylum seekers, and specifically those who entered from the U.S. between official ports of entry and made a claim for asylum in 2017 and 2018. More notably, I am interested in the coverage and portrayal of these individuals and their actions by Canadian news media during this two-year period. It was a phenomenon widely covered by Canadian news media outlets, fueling societal and political debate about the situation at hand and what ought to be done. Utilizing critical discourse analysis, I will seek to answer the question: How did news media depict, portray, and frame asylum seekers who crossed the border between ports of entry into Canada from the U.S. in 2017 and $2018 ?$

Critical discourse analysis is an interdisciplinary approach to studying discourse, and according to van Dijk (1995), a "socio-politically conscious and oppositional way of investigation language, discourse, and communication" (p. 17). In this way, critical discourse analysis is a significant tool of investigation to understand how news media discursively represents and constructs social actors, which in the case of this research project, refers to asylum seekers. According to Tolley (2016), news media determines for us "which stories are covered, how subjects are portrayed, and the standards by which events, issues and personalities are understood and evaluated" (p. 15). Therefore, news media play a critical role in disseminating information, telling stories, and providing insight into the world around us (Tolley, 2016). While the scope of this research project does not include the measurement of the attitudes of the Canadian public on asylum seekers or the implications of the news media coverage, a 
survey from the Angus Reid Institute (2018) which polled 1,500 Canadian adults in 2018 can offer some insight. When asked for their opinions on asylum seekers crossing into Canada between ports of entry, 67 per cent answered that the situation was a "crisis," and that "Canada's ability to handle the situation is at a limit" (Angus Reid Institute, 2018). The remaining 33 per cent answered that "this situation is not a crisis, the situation is being overblown by politicians and the media" (Angus Reid Institute, 2018). About 65 per cent felt that Canada had taken in "too many irregular crossers" for the Canadian government and service agencies to handle (Angus Reid Institute, 2018). About 29 per cent answered that they felt that the number of asylum seekers was a "manageable number of people for Canada to handle," and 6 per cent answered "this is a small number of people, Canada can handle more" (Angus Reid Institute, 2018). Almost half of respondents (48 per cent) overestimated how many asylum seekers had entered the country, believing it was more than 50,000 (rather than the actual 30,000 who had entered at the time of the survey). The Angus Reid Institute (2018) notably found that those who overestimated the number of people crossing between ports of entry were "more likely" to perceive the issue as a crisis. It is worth clarifying that respondents represented a range of political ideologies: over 50 per cent reported that they had voted for the Liberals and New Democrats in the 2015 federal election (Angus Reid Institute, 2018).

On this issue, the Angus Reid Institute (2018) found that the awareness among respondents on the topic of asylum seekers crossing between ports of entry was higher than with other issues. When asked how the respondents learned about the subject, 70 per cent answered that they were following along on the news and paying attention to some media coverage (while also discussing it with peers). 20 per cent answered that they had gotten the information from 
scanning "just the headlines," while 10 per cent answered that they had not heard about the issue. This data is supported by Torkington and Ribeiro (2019), who posit that migration issues in contemporary societal and political debates has attracted "the focused attention of the media" which in turn, plays a critical role in "shaping and (re)directing public opinion on migration issues" (p. 22). In other words, news media influences "ways of knowing and believing" in news media readership (Torkington \& Ribeiro, 2019, p. 23). Given that forced migration will undoubtedly continue to place pressures on wealthier nations in the Global North to respond, especially as the Global South reaches its limitations to do so, these findings demonstrate the important role that news media play in framing the topic of irregular migration for Canadians. This also speaks to the influence that news media has on the way in which Canadians perceive those individuals who seek asylum and are granted refuge in society. This research project will contribute to the body of existing research that has similarly analysed and dissected the discursive practices employed by news media on their depiction of migrants coming to and those already residing in Western democracies. My research will demonstrate how Canadian news media in 2017 and 2018 primarily employed problematizing discourse to depict, portray, and frame asylum seekers who crossed the border between ports of entry into Canada from the U.S. over a two-year period. My analysis revealed that asylum seekers are primarily homogenized and collectivized in negative ways that fuel the perception that they are a problem, combined with their position as distinctly separate from Canadians. My hope is that this research project will help readers develop a more critical approach to and keener understanding of news media coverage on asylum seekers. I believe this in turn can lead to more engaged citizens and voters 
who can assess for themselves what to make of asylum seekers crossing between ports of entry in Canada from the U.S.

To offer context for this research project, I will first offer my positionality. As a woman and second-generation Canadian who belongs to a racial minority group, and who is also employed by a public, post-secondary institution in a communications role, I am interested in how powerful institutions that control communication channels and employ specific discursive strategies are used to depict marginalized communities. Liberal immigration policies forged a pathway for my parents to immigrate to Canada based on the social capital they were perceived to offer the country. And yet, even with multiculturalism policies which promote the inclusion of all people regardless of ethnoracial identity, the lived experience of my family has not always reflected Canadian ideals of diversity. Despite this, I acknowledge that I have been the beneficiary of incredible opportunities and privileges, and therefore feel empowered to critically analyse the opportunities and privileges from which I have benefited in this white settler nation now called Canada. My journey through Ryerson's Immigration and Settlement Studies program has been a significant opportunity in my lifelong commitment to learn and unlearn ideas, attitudes, and beliefs about marginalized group experiences, including my own, with the ultimate goal of finding new pathways for resistance to dominant systems which subordinate some and privilege others. By learning more about the power of news media and their depictions of migrants in search of better lives, my hope is that as a communicator and activist, I can find ways to work in solidarity with those impacted by problematizing discourse. 


\section{Context}

Before diving into the subject of this paper, I will offer some context, including key terms and definitions, the current state of forced migration across the globe, the role of news media from the perspective of critical discourse analysis, and the relevant geopolitical background.

\section{Key Terms and Definitions}

An asylum seeker is a person who has been forced to flee their habitual residence and is applying for asylum to be recognized as a refugee in another country (UNHCR, 2006). When their claims for asylum are to a country with procedures in place to evaluate refugee claims, they maintain their status as an asylum seeker while their claims are being assessed (UNHCR, 2006). Once evaluated, some asylum seekers will be granted refugee status, while others will be denied this recognition (UNHCR, 2006). While not all asylum seekers meet the eligibility criteria to be recognized as refugees, all refugees initially begin as asylum seekers (UNHCR, 2006). The aforementioned eligibility criteria is based on the definition of a refugee set out by the 1951 Convention Relating to the Status of Refugees, a United Nations treaty to which Canada is a signatory (UNHCR, 2010; Atak, 2018). The Convention is an international agreement that was created following the Second World War which saw the displacement of over 40 million people (Philo, Briant, \& Donald, 2013). It established that a refugee is a person who-because of war, violence, or persecution — has been forced to flee their country of origin, and is unable to or cannot return (UNHCR, 2010). In this way, a refugee is evaluated on the basis that they demonstrate a "well-founded fear of persecution for reasons of race, religion, nationality, political opinion, or membership in a particular social group" (UNHCR, 2010, p. 3). Protection under international refugee law affirms the rights of refugees, as well as the corresponding legal 
responsibilities and protections required of the countries that accept them (UNHCR, 2010).

Primarily, countries have a responsibility to protect refugees and cannot return them to conditions that will further put their safety at risk (UNHCR, 2018). It is also important to note that asylum seekers and refugees (as well as immigrants of all kinds, including expats) fall under the umbrella category of a migrant: a person who has left their regular residence to live in another region or country (International Organization for Migration (IOM), 2011). The term migrant applies regardless of the person's legal status, regardless of whether or not the movement was of their own volition or forced by other factors (IOM, 2011). This research project will focus specifically on asylum seekers.

\section{The Global Context of Forced Migration}

According to the UNHCR (2019a), currently across the globe, 41.3 million people are internally displaced within their own countries, 25.9 million have already received refugee status and are living in another country, and 3.5 million are actively seeking asylum in other countries. A critical piece of context required to understand this phenomenon is that the majority of forced migration derives primarily from the Global South, and that the majority will remain close to home, finding refuge in neighbouring regions and countries (UNHCR, 2019a). In other words, 85 per cent migrate to neighbouring countries from which they came within the Global South (UNHCR, 2018). As an illustration of this reality, in the case of the 6.7 million Syrians displaced since 2011 because of civil war, the majority are now residing in neighbouring Turkey (UNHCR, 2019a). For the 3.4 million Venezuelans displaced because of violence, food insecurity, and lack of essential services like medical care, most have sought refuge in neighbouring Colombia (UNHCR, 2019b). Indeed, the UNHCR (2019a) reported that approximately 68 per cent of 
people displaced worldwide came from just five countries: the Syrian Arab Republic (6.7 million), Afghanistan (2.7 million), South Sudan (2.3 million), Myanmar (1.1 million) and Somalia (0.9 million). As such, the corresponding five countries that hosted the most refugees in the same year were Turkey (3.7 million), Pakistan (1.4 million), Uganda (1.2 million), Lebanon (1.1 million), and the Islamic Republic of Iran (1.1 million) (UNHCR, 2019a).

This data puts into perspective the global refugee crisis and what has been called the greatest humanitarian crisis since the Second World War: the most significant impacts are not on Western democracies like Canada, but primarily on Global South countries (UNHCR, 2018). Indeed, Canada (ranked the tenth wealthiest country in GDP valuation in 2018) recorded just over 105,000 asylum claims in 2017 and 2018 (Statistics Times, 2019; Government of Canada, 2019a; Government of Canada, 2019b). Put into perspective, this is a mere 0.03 per cent of those seeking asylum worldwide. As UNHCR's Canada Representative, Jean-Nicolas Beuze stated: When we're speaking about a crisis, a crisis of refugees does exist - but it's not in Canada, it's not in the U.S., and it's not in Europe. The big numbers remain in the developing world, whether it's Bangladesh, Uganda, Lebanon - those are the countries that are facing a refugee crisis. (as cited by Grant, 2018) Therefore, despite the reality of this humanitarian crisis, the response from Global North countries has been minute compared to those in the Global South. This information is critical to understanding this issue, and counters the common misconception that refugees are primarily settled by Western democractic nations (Philo et al., 2013). 


\section{The Role of News Media}

Critical discourse analysis assumes that news media discourse is not merely a product of the text producer or journalist, rather it is a reflection of the ideals of powerful groups and institutions (Richardson, 2007). While citizens in liberal democracies expect news media to be neutral, objective, and fair in its representation of viewpoints from all groups, Henry and Tator (2010) posit that media institutions are "instruments" by which the ideals of dominant groups are reproduced, perpetuated, and maintained (p. 256). Richardson (2007) adds that journalism is "intimately linked with the actions and opinions of (usually powerful) social groups" (p. 1). In other words, news media is not neutral or immune to the social inequalities and discrimination present in Canadian society; they transmit the dominant values, myths, and cultural standards of the time (Henry \& Tator, 2010).

Despite that relatively few refugees end up in the Global North, there has been a rise in negative public sentiments in Western democratic nations regarding the entry of asylum seekers and settlement of refugees (Porter \& Russell, 2018). News media has covered and contributed to this discourse, and it has reported to have heavily influenced the fate of political movements and elections alike, backed by politicians in Global North countries who have made promises and enacted measures to prevent migrants from crossing their borders (Porter \& Russell, 2018). This includes, but is not limited to, the election of Donald Trump as the president of the United States in 2016 and the vote in the same year which established that Britain will leave the European Union (Porter \& Russell, 2018). Across the rest of Europe, intense public anxiety about the settlement of migrants, exacerbated by economic hardships, has led to hardened views and increasingly restrictive border controls to limit the entry of asylum seekers from the Global 
South (Berry et. al., 2015). Indeed, Torkington and Ribeiro (2019) share that given news media has intensely focused in on migration issues in contemporary societal and political debates, the discourse it produces plays a critical role in influencing public opinion.

In spite of the tragedy of the circumstances that force migrants to leave their homes, including war, armed conflict, human rights violations, and environmental disasters alike, existing research and analysis, primarily from Europe and Australia, found that news coverage often problematizes and characterizes migrants as a burden for receiving societies to bear (Berry et al., 2015). This is reflected in specific discursive strategies that news media employ to tell the stories of migrants, reflective of the opinions and ideologies of news media institutions and the societies to which they belong (Richardson, 2007). This research project will employ critical discourse analysis to similarly explore what kind of discursive strategies were employed by Canadian news media in 2017 and 2018 that focused on the entry of asylum seekers from the U.S. between ports of entry.

\section{Trump's Anti-Immigration Stance and Trudeau's Response}

Of significance to this research is the 2016 election of U.S. President Donald Trump. Immigration was a focal point of his campaign as well as a series of promises that his administration would enact measures to control the entrance of migrants he deemed illegal and undesirable (Pierce \& Selee, 2017; Bender, 2019). This included the promise of building a wall along the U.S.-Mexico border to restrict the access of migrants from South America (Pierce \& Selee, 2017; Bender, 2019). This was one of his principal campaign promises and as reported by Porter and Rossell (2018) and Bender (2019), a key factor central to his successful candidacy. Throughout his tenure, he has continually promised to crackdown on "illegal" immigration, 
portraying migrants without status as a significant threat to national security and the economy (Steinberg et. al, 2018, p. 210; Pierce \& Selee, 2017). He also promised that he would enact "extreme" vetting procedures of migrants, prioritizing the needs of Americans and the economy first and foremost (Pierce \& Selee, 2017; Bender, 2019).

In step with his campaign promises, on January 27, 2017, just seven days after his inauguration, the Trump administration signed Executive Order 13769, with the aim to ban foreign nationals from seven predominantly Muslim countries (Pierce \& Selee, 2017). This order was meant to restrict the entry of foreign nationals from Iran, Iraq, Libya, Somalia, Sudan, Syria, and Yemen into the U.S. (Pierce \& Selee, 2017). He also went on to cancel the Deferred Action for Childhood Arrivals (DACA) program; suspend the entrance of all Syrian refugees indefinitely; and prohibit refugees from other countries for 120 days (Steinberg et. al, 2018; Pierce \& Selee, 2017). Then on November 20, 2017, Trump announced that he would make efforts to end the measures to protect the status that had been granted to Haitians through the Temporary Protected Status program (Cohn, Passel, \& Bialik, 2019). At the time of the announcement, roughly 318,000 people were beneficiaries of this protection (Cohn et al., 2019). Still struggling to recover from a devastating earthquake in 2010, these Haitian nationals have been able to work in the U.S., providing them with economic opportunities unavailable to them in Haiti (Cohn et al., 2019).

These immigration policy changes have been highly publicized by news media, as they have effectively put into precarity the status of many migrants in the U.S. (Pierce \& Selee, 2017; von Scheel, 2019). Moreover, the changes have been widely reported to have motivated the migration of people to Canada in search of asylum (Pierce \& Selee, 2017; von Scheel, 2019). 
Some migrants, either formally rejected or afraid that they would be rejected by the U.S., have feared that Trump's "crackdown" on undesirable refugees and undocumented migrants alike will lead them to be forced to return to their countries of origin (Steinberg et. al, 2018, p. 210; Goldring, Berinstein, \& Bernhard, 2009). In response to Executive Order 13769 which was dubbed "the Muslim ban," Canadian Prime Minister Justin Trudeau posted on social media: "To those fleeing persecution, terror, and war, Canadians will welcome you, regardless of your faith. Diversity is our strength \#WelcomeToCanada." These 20 words made up a single Twitter post and caught the attention of many, drawing a sharp contrast between the stance on immigration between the two countries and its leaders (Nimijean, 2018).

This communication from Trudeau is also cited to have influenced refugees across the globe, especially migrants with precarious status in the U.S., to look hopefully towards Canada as a place that they may be successfully granted refugee protection (Nimijean, 2018; Dawson, 2018; Woods, 2017). It is considered to have contributed to the increase in the number of asylum seekers willing to take the risk, often at great cost to their physical well-being, of crossing between ports of entry along the Canada-U.S. border for the chance of receiving refugee status in Canada (Woods, 2017; Nimijean, 2018; Smith, 2018; Statistics Canada, 2019). According to Smith (2018), who analysed the Canadian government's records through the National Post's access-to-information request, after Trudeau's tweet was sent on January 28, 2017, officials within the government and at Canadian embassies abroad received a significant increase in refugee inquiries, including from nationals from the list of countries impacted by Executive Order 13769. Internal Canadian government communications make evident the confusion caused by the tweet among Canadian officials abroad, as well as pressure on the government to devise 
an official response (Smith, 2018). The Canadian government and Trudeau officially stood by the initial message, but were required to clarify and reiterate that there are official channels that asylum claimants are obligated to follow (Smith, 2018). Indeed, despite the implied meaning of Trudeau's tweet, there were no changes to Canada's refugee resettlement program, and opposition politicians, critics, and media alike have attributed the message as to why there has been an increase in irregular migration at the Canada-U.S. border (Smith, 2018). This in turn has garnered significant attention from Canadian news media, and it is this discourse that I will seek to analyse, employing Norman Fairclough's methodology of critical discourse analysis.

\section{Canada-United States Safe Third Country Agreement}

Of critical significance to this research project is the Canada-United States Safe Third Country Agreement, a treaty between the Government of Canada and the Government of the U.S., which went into effect in 2004 to help both governments "better manage access to the refugee system in each country for people crossing the Canada-U.S. land border" (Government of Canada, 2016). Under the Agreement, asylum seekers are required to make their claim for refugee status in the "first safe country they enter" after leaving their country of origin (Goldring et al., 2009). Canada and the U.S. are both considered "safe" countries, meaning that those who seek refuge in Canada but are located in the U.S. (or travel by way of the U.S.) are required to remain there to make their request (Golding et al., 2009; Government of Canada, 2016).

However, the Agreement only applies to those claims made at official air, land, or marine ports of entry, not to those who enter between ports of entry. Given that the border between those official crossings is mostly unguarded, once a migrant has stepped over the invisible line between the two countries and are effectively on Canadian soil, the country is responsible to 
provide them with a chance to make an asylum claim as per the Convention. Had these same individuals crossed at an official port of entry, they would have been immediately returned to the U.S. and required to make their refugee claim there.

This treaty and its criteria based solely on official ports of entry has been framed as effectively facilitating the entrance of the approximately 40,000 asylum seekers crossing into Canada between these crossings (Government of Canada, 2019a; Government of Canada, 2019b). Indeed, many of the migrants who have entered into Canada between ports of entry likely knew that they would be able to claim asylum more immediately than if they had done so from the U.S. (Woods, 2017). For Canadian border officials who discover these individuals along the border between ports of entry, they have no jurisdiction to prevent migrants from crossing when they are on the U.S. side. Once they are in Canada, they are obligated to grant asylum seekers access to the legal system that evaluates refugee status, and without differentiation from those who seek asylum from the U.S. (Atak, 2018, p. 176).

For those who enter into Canada at the most commonly-traversed crossings between ports of entry, the migrant is likely to be apprehended by the RCMP and will usually undergo a security screening (Grant, 2018; Zimonjic, 2018). If their claims for asylum meet the initial eligibility requirements, their cases will be turned over to the Immigration and Refugee Board (IRB) (Grant, 2018; Zimonjic, 2018). This process can take anywhere from 12 to 24 months, and they are permitted to remain in Canada while they wait (Grant, 2018; Zimonjic, 2018). They may also be provided with social assistance, support to find housing, access to health care, and education for children (Stevenson, 2017). Despite their entitlements to social assistance, many of these individuals are in legal precarity, and face barriers to finding suitable permanent housing, 
childcare, or employment (Markusoff, 2018). Overall, the criteria in the Canada-United States

Safe Third Country Agreement has been cited as to why migrants have chosen to cross between, rather than at, official ports of entry (Grant, 2018). Now with an overview of key terms and context required to understand the main topic of this research project, I will provide an overview of existing research that analysed news media coverage of migrants to and in Western countries.

\section{CHAPTER 2}

\section{Existing Scholarly Research on News Media Framing of Migrants}

This section will provide an overview of existing scholarly research that similarly analysed and probed at news media discourse concerning migrants (including asylum seekers, refugees, and temporary migrant workers) in Western democratic nations. Critical discourse analysis frames the inclusion of existing literature as necessary because it provides overall sociocultural context to one's own analysis (Richardson, 2007).

A predominant theme in the literature was that news media coverage commonly framed refugees as "the other," which contributed to "us" and "them" divisions (Cartner, 2009; KhosraviNik, 2010; thor Straten, 2016; Kyriakides et al., 2018). According to Machin and Mayr (2012), "us" and "them" divisions align the reader "alongside or against particular ideas"; it involves the text producer or journalist presenting their ideas as if they are widely held, then creating a "collective 'other" in opposition to those same ideas (p. 84). This kind of representation was foundational to much of the analysis found in the literature in which both groups - members of the receiving nation and the migrants—-were characterized by homogenous group characteristics in opposition to one another (Kyriakides et al., 2018). Members of the receiving nation were commonly positioned as willing and generous hosts, its members 
connected through shared citizenship, belonging, access to resources, and values (Kyriakides et al., 2018). On the other hand, migrants, including refugees and asylum seekers, were represented as outsiders and a single, often overwhelming, force that had the potential to compromise the nation's values, norms, and systems (Cartner, 2009; KhosraviNik, 2010; thor Straten, 2016).

Several researchers further demonstrated how racialized discourse has inferiorized migrants while simultaneously reinforcing and upholding the superiority of Western values (Cartner, 2009; KhosraviNik, 2010; Lueck, Due, \& Augoustinos, 2015; thor Straten, 2016). Cartner's (2009) analysis specifically demonstrated how news media reinforced binary representations that framed White Australians as heroic saviours while non-White refugees were negatively framed as "uncivilized and savage" individuals who put themselves and their families at risk (p. 25). Meanwhile, analysis by Philo et al. (2013) specifically revealed how some British newspapers implied that the local population was at risk of harm by migrant groups, speculating on diseases that the migrants carried with them. This discourse is grounded in Edward Said's theoretical framework of Orientalism; this discourse reinforces the binary opposition of two group identities that can contribute and fuel ethnic nationalism: the migrant as "the other" in opposition to a national "self” (Bauder, 2008, as cited by Hynie, 2018).

Another theme identified in the literature was how asylum seekers and refugees were depicted within neoliberal frameworks that commodified them as low value to the receiving nation because of their perceived lack of human capital (Lueck et al., 2015; thor Straten, 2016). Asylum seekers and refugees were commonly framed as a "drain" on public resources because of their overall disadvantaged economic standing, ascribed to their origins from the Global South (Tyyskä et al., 2018, p. 150; Lueck et al., 2015). In this way, asylum seekers and refugees were 
framed as both burdens to the economy and a threat to social services that the receiving population were entitled to (Berry et al., 2015; Lueck et al., 2015; 2012; thor Straten, 2016). Moreover, migrants were generally depicted as impermanent outsiders with restricted rights to public services (Nail, 2015). The analysis of thor Straten (2016) specifically found that news media framed refugees as taking housing benefits meant for Danish residents. In general, migrants were commonly framed in competition for a limited number of resources and services (Berry et al., 2015; Lueck et al., 2015; thor Straten, 2016). Furthermore, in some cases the poor economic prospects of the country were attributed to asylum seekers and refugees rather than the government's poor economic policy and inability to stimulate economic growth (Lueck et al., 2015; thor Straten, 2016). These representational strategies further fueled the "us" and "them" division between migrants and members of the receiving nation (Berry et al., 2015; Lueck et al., 2015; thor Straten, 2016). Lueck et al. (2015) specifically found that neoliberal ideologies were further used to justify the major economic investments required of policing and judicial institutions to enforce policies and practices in order to protect borders "by force if need be" to ensure "the proper functioning of [the country's] markets" (p. 610). The analysis in the existing literature further revealed how news media justified strict law enforcement measures in the name of protecting the assets that members of the receiving nation were entitled to (thor Straten, 2016).

Several researchers also identified a common theme whereby asylum seekers were framed in discursive ways that cast doubt on whether or not they are legitimately refugees, implying that they were undermining and abusing immigration systems (Hynie, 2018). These narratives focused primarily on "binaries of legitimate-illegal" migrants and was preoccupied with the legitimacy of their asylum claims, implying that some were truthfully wealthy migrants 
moving for economic purposes rather than legitimate fears of persecution (Ashutosh \& Mountz, 2012). Further analysis by Berry et al. (2015) demonstrated how news media fueled the perception that immigration systems were "compromised," and that institutions were vulnerable to the trickery of criminals looking to infiltrate and harm receiving nations (p. 15). In other words, asylum seekers were framed as a threat to institutional stability and equilibrium. According to Henry and Tator (2010), the fear of the destabilization of economic and political institutions can ignite the discourse of the moral panic which is characterized by feelings of anxiety and fear of the unknown.

The discourse of moral panic was also found in the analysis of news media that revealed representational strategies of aggregation employed by news media, specifically "numerical elements" paired with "intensifying adverbs" to describe the movement and entrance of migrants (KhosraviNik, 2010, p. 13). The analysis of Philo et al. (2013) demonstrated specifically how British news media put a strong emphasis on numbers which quantified individuals and treated them like statistics. Instead of focusing on the human impact of so many being forced to migrate, news media used "vague and indeterminate" rounded-up numbers to give the audience a sense of how immense the group was (Philo et al., 2013, p. 105). Several researchers also found a common use of metaphors to aggregate asylum seekers, including words like 'waves,' currents,' 'floods,' 'influxes,' 'masses,' and 'swamping," framing them as having the potential to overtake the receiving nation (Philo et al., 2013; Behrman, 2014; thor Straten, 2016). Inouye's (2012) analysis specifically demonstrated how temporary foreign workers were likened to a threatening "swarm of bees," framed as a "nuisance" when they voiced their concerns over unfair labour practices (p. 583). The use of these representational strategies effectively dehumanized migrants 
by equating them with inclement weather and pests, reducing them to an overwhelming problem rather than as individuals seeking refuge from dire circumstances or advocating for more fair working conditions (Behrman, 2014).

Significantly, several researchers found in their analysis that the discourse representing asylum seekers and refugees often excluded the larger context in which migrants are active agents who chose to leave dire conditions in order to seek out better lives for themselves and their families (Behrman, 2014; Lueck et al., 2015). Despite that context in which migrants are seeking asylum from factors like violence and war, the existing research shows that migrants have often been characterized as perpetrators of conflict in receiving societies (KhosraviNik, 2010). Paradoxically, asylum seekers were also commonly framed as having little agency and autonomy, depicted as "an undifferentiated mass, lacking the skills and the sophistication of the settled citizenry" (Behrman, 2014, p. 249). Instead of being depicted as resilient individuals fighting (and deserving) of better living conditions, they were commonly evaluated by news media from the perspective of those in the receiving nation and framed primarily as unworthy or not truly deserving of refuge (Kyriakides et al., 2018, p. 60).

Furthermore, Berry et al. (2015) specifically found that very few European news media articles focused on the benefits that migrants could offer receiving countries. Indeed, the analysis revealed how news media often negated the potential human capital and talents that asylum seekers may have brought with them; they were often framed as disadvantageous to society because they lacked the skills and capital to easily enter the labour market, often because of their dependency on government assistance (Root et al., 2014). In turn, some news media also justified the rejection of asylum seekers at its borders because of the large public investment they 
would engender while offering no immediate financial benefit in return (Every, 2006). This lack of positive framing of asylum seekers or inclusion of narratives based on humanitarianism was clearly evident in the existing research (Berry et al., 2015). Now with an overview of the existing research that analysed news media coverage of migrants, I will offer my own critical discourse analysis of news media in Canada and their depiction of asylum seekers crossing between ports of entry from the U.S. My findings will contribute to the existing body of literature to increase the understanding of discourse concerning asylum seeking refugees by Canadian news media.

\section{CHAPTER 3}

\section{Methodology of Critical Discourse Analysis}

This research project will analyse news media coverage of asylum seekers who attempted to enter into Canada between official ports of entry from the U.S. to make a refugee claim from January 2017 to the end of 2018. The use of critical discourse analysis, and specifically Fairclough's approach, will help me uncover and reveal the ideologies and social issues that lie behind news media discourse (Richardson, 2007; Jørgensen \& Phillips, 2002). Discourse is a grouping of text and statements, produced by individuals and institutions, that represent the specific way in which a topic can be understood (Hall, 2018). Hall (2018) concedes that discourse involves a body of "statements working together" to create "discursive formation" which produces meaning (p. 86). Critical discourse analysis begins with the identification of a social problem (which in this case is asylum seekers entering into Canada between ports of entry) and then as per van Dijk (1996), "chooses the perspective of those who suffer the most, and critically analyses those in power, those who are responsible, and those who have the means and the opportunity to solve such problems" (as cited by Wodak, 2001, p. 1). 
In this way, critical discourse analysis is both a theoretical framework as well as a method to allow for the study of discourse and its relationship within the social and cultural context that it is borne of (Richardson, 2007; Jørgensen \& Phillips, 2002). Fairclough's approach to critical discourse analysis acknowledges three dimensions to discourse. The first dimension is the text itself, the second is the discursive practice in which the text was produced and how it is later consumed, and the last is the social practice: the political, historical, and social context and society in which the texts were created (Richardson, 2007). In other words, discourse is both a social practice and an element itself that influences all social practices (Mogashoa, 2014; Jørgensen \& Phillips, 2002). Richardson (2007) describes this as a "circular process": news media discourse is influenced by the media institution it comes from, the society, and the sociopolitical context in which it was created, and simultaneously influences those same factors (Jørgensen \& Phillips, 2002). As an illustration of this, discourse can be a tool of discrimination functioning on behalf of systemic racism to augment prejudiced ideologies; it can reflect discrimination when it reinforces the ideologies that sanction the exclusion of certain groups from resources they require to fully participate in society (KhosraviNik, 2010). Therefore, given that critical discourse analysis assumes that language is much more than words and implies specific political and social meaning, this method will allow for the "ideological assumptions" to be revealed within news media discourse concerning asylum seekers who cross into Canada between ports of entry (McGregor, 2010, p. 4; Mogashoa, 2014). Critical discourse analysis is distinguishable from other forms of linguistic analysis because of the way it examines the overall political, historical, and social context from which it derives (Richardson, 2007). According to 
Richardson (2007), critical discourse analysis "takes an overt moral and political position with regard to the social problem [being] analysed" (p. 2).

This research project analyses how Canadian news media has portrayed migrants who crossed into Canada from the U.S. between ports of entry from 2017 to 2018. I examined news coverage from two English-language newspapers in Canada, the Globe and Mail and the National Post, from January 1, 2017 to December 31, 2018. This two-year period from 2017 to 2018 is significant because it marked the beginning of Donald Trump's tenure of President of the U.S. when he enacted radical changes to American immigration policies (Zilio, 2019; Bell, 2017). This, along with Trudeau's widely-disseminated response on Twitter, has been widely reported to have been a key motivating factor which led some migrants to seek asylum in Canada (Zilio, 2019; Bell, 2017). Indeed, while the total number of asylum claimants to Canada has fluctuated over the last two decades, with major peaks in 2001 (approximately 44,600), and 2008 (approximately 36,800), there was a significant increase in 2017 (approximately 50,400) and 2018 (approximately 55,000) (Statistics Canada, 2019). Notably, this was over double the number of asylum claims in 2016 (approximately 23,900) (Statistics Canada, 2019). Statistics Canada (2019) attributes this increase to the number of irregular migrants who crossed between ports of entry. Indeed, out of these totals number of asylum seekers to Canada in 2017 and 2018, RCMP's reports show that 20,600 (37 per cent) in 2017 and 19,400 (35 per cent) in 2018 were irregular migrants (Government of Canada, 2019a; Government of Canada, 2019b). Initial results from the first half of the year show that the number of asylum seekers crossing between ports of entry in 2019 has decreased compared to the previous two years (Connolly, 2019). 


\section{Data Collection and Inclusion}

The Globe and Mail and the National Post were chosen because they are the country's national, daily, English-language newspapers in Canada (Meyer, 2017; Chepkemoi, 2019). The Globe and Mail has the higher circulation of over 320,000 while the National Post has a circulation of approximately 180,000 (Chepkemoi, 2019). Given the scope of this research project, the inclusion of two national papers offered a sufficiently rich source of data to analyse, both with a country-wide perspective. Besides their national focus and breadth, another significant factor that influences content framing are the backing ideologies of media institutions (Lawlor \& Tolley, 2017). According to Media Bias Fact Check (an independent online media outlet that aims to educate the public on media bias), both the Globe and Mail and the National Post have moderately conservative, politically right-wing biases (Van Zandt, 2018; Van Zandt, 2019). Van Zandt (2018) explains that right-of-centre biased news media outlets tend to "publish factual information that utilizes loaded words (wording that attempts to influence an audience by using appeal to emotion or stereotypes) to favor conservative causes" (para. 1).

The discourse body (or data set) of this research project includes 70 editorial, news, and opinion articles from both papers. Editorial articles reflect the position of newspaper management; they are not attributed to individual authors (Blidook, 2009). News articles are those that aim to report on facts in an impartial manner by news reporters, with the aim to objectively portray what actually happened (Blidook, 2009). Meanwhile, opinion articles are those that include the personal interpretation of the facts of the story, usually by one of several regular contributors of the news outlet (Globe and Mail, n.d.). The information used for analysis was obtained from the online, digital archives of the newspapers themselves. In order to locate 
the articles, I performed a search on each paper's search tool using the words "asylum seeker." I opted to utilize online versions of both newspapers because they offered a readily available and organized collection.

The Globe and Mail. A search on the Globe and Mail's website of the words "asylum seeker" produced 1,670 results on July 5, 2019. I scanned the initial search results and the information provided: the article title, author, and initial publication date. I excluded those outside of the timeframe of this research project: before January 1, 2017 and after January 1, 2019. Then I excluded articles with titles that were on the topic of asylum seekers in other parts of the world, including the U.S. and Europe. After this, I scanned the text of any article that met the timeframe and had a title that appeared relevant to Canada. Articles that referred to the topic of asylum seekers in Canada, but not between ports of entry, were excluded. Articles that were newsletter types with briefings that provided only a snapshot of the headlines about asylum seekers were also excluded, rather, the actual full articles referred to were included. While letters to the editor sometimes expressed opinions on the topic, they were excluded given the scope of this research project is on the news media coverage itself. I also excluded those in which asylum seekers were obviously peripheral to the main topic of the article.

After this initial assessment, I was left with 245 articles, which I collected and categorized into a spreadsheet by parsing out the following data for each: publication date, web address of the article, title, summary (if applicable), and author. With these articles placed into the spreadsheet on individual rows, I sorted by author and removed all articles that were authored by newswire agencies including the Canadian Press, the Associated Press, and Reuters. Newswire agencies like these employ correspondents who prepare and offer content to Canadian 
news media outlets on a paid subscription basis. Their staff reporters utilize content in their own articles or sometimes news media outlets publish entire articles produced solely by newswire correspondents. I excluded articles that were authored solely by newswire agencies because the writers who prepare the content are not employed by the Globe and Mail themselves.

I also excluded news stories attributed to freelance reporters and opinion pieces attributed to outside contributors who are not Globe and Mail staff members, rather public figures, professional, and/or academic experts in specific fields. This left a remaining 131 articles. I then added a new category in the spreadsheet to distinguish the article type and attribution: editorial articles by the Globe and Mail, news articles attributed to individual Globe and Mail staff members, and opinion articles attributed to individual Globe and Mail staff members. I then conducted a more thorough and in-depth reading of each article to understand if asylum seekers were peripheral to the topic of the article rather than the main subject matter. For example, the news article "Hundreds of Canadian children held in immigration detention, report shows" was about the findings of a report which revealed how the Canadian children of foreign nationals or permanent residents who are detained under the Immigration and Refugee Protection Act have been held in immigration detention centres (Friesen, 2017). While this article was about asylum seekers, its focus was on Canadian children already in the country, rather than on the children of those asylum seekers in 2017 and 2018 who crossed between ports of entry, and was therefore excluded. This exercise resulted in 13 articles being eliminated, leaving 116 remaining articles: 11 editorial articles, 79 news articles, and 26 opinion articles.

The National Post. The same inclusion and exclusion criteria, as well as search strategy was applied to the National Post. The initial search using the words "asylum seeker" produced 
1,936 results on July 6,2019 . After excluding those articles that were published outside of the timeframe of this research project, articles on the topic of asylum seekers in other parts of the world, and those on the topic of asylum seekers in Canada, but not between ports of entry, I was left with 277 articles. With these articles placed into the spreadsheet, I sorted by author and removed all articles that were authored by newswire agencies including the Canadian Press, the Associated Press, the New York Times, Presse Canadienne, and the Wall Street Journal. I also excluded news stories attributed to freelance reporters and opinion pieces attributed to outside contributors like public figures, professional, and/or academic experts in specific fields. I also eliminated articles that were written by contributors who are not primarily journalists. This included articles authored by an organization called the Conversation, which much like newswire agencies, offer reporting by academic experts. This resulted in 208 being eliminated, leaving a remaining 69 articles. I then added a new category for each article to distinguish the article type: editorial pieces (attributed to the National Post View), news stories by National Post staff members, and opinion pieces by individual National Post staff members.

Following this categorization, I read each article and exclude those who's mention of asylum seekers was peripheral to the topic of the article rather than the main subject matter. For example, the National Post editorial article by Coyne (2017) titled "Andrew Coyne: How should Canada respond to Trump? By doing things we ought to be doing anyway" was concerning the government's response to Trump's policies and mentioned asylum seekers as a factor to consider, but was not the main focus (Coyne, 2017). This exercise resulted in 9 articles being eliminated, leaving 60 remaining articles: 3 editorial articles, 30 news articles, and 27 opinion articles. 
Random Sampling. With the aim to analyse 35 articles from each paper, I randomly sampled from the overall data set. First I calculated what percentage of the total sample were editorial, news, or opinion articles. Using Google Sheets, I applied a formula to extract random cells which led to my final data set: 3 editorial articles ( 9 per cent), 24 news articles (68 per cent), and 8 opinion articles ( 23 per cent) from the Globe and Mail, and 2 editorial articles (6 per cent), 18 news articles (51 per cent), and 15 opinion articles ( 43 per cent) from the National Post (Appendix A: Data Set). The shows a significantly higher number of opinion articles by the National Post. I argue that the disproportionate amount of coverage by opinion columnists conveys the importance of the issue for the National Post, carving out a distinctive position on the issue in the Canadian news media landscape. Critical discourse analysis involves interpretation and contextualization by the analyst themselves; there are few prescriptive guidelines. Because of this, I opted to follow the expertise of Richardson (2007) on Fairclough's method of critical discourse analysis to formulate data extraction questions to ask of each article, focused on examining the social practices, discursive practices, and choices made by the writer (Appendix B: Data Extraction Questions).

\section{CHAPTER 4}

\section{Analysis of News Media Articles}

My analysis involved 70 articles from two Canadian English-language newspapers with national circulation from 2017 and 2018. Overall, my analysis found numerous themes in common with those found in the existing literature as summarized in chapter 2. Asylum seekers were similarly depicted, portrayed, and framed in problematizing ways. My analysis found that news media employed discursive strategies that perpetuated "us" and "them" divisions, 
representing asylum seekers as in opposition to members of the receiving nation and its national interests. Moreover, I identified specific representational strategies of aggregation and functionalization that contributed to the dehumanization of asylum seekers. While many articles sourced the Trump administration's immigation policy changes and Canada's overall reputation of openness as motivating factors that led them to cross between ports of entry, very few contextualized the issue within the larger, humanitarian crisis afoot. Few articles focused on how Canada could use this as an opportunity to take leadership and support those in search of refuge worldwide. The following section will systematically outline the recurring themes which served to problematize asylum seekers as a burden for Canadian society, politicians, and institutions. I

will also present an analysis of some articles which sought to humanize and individualize asylum seekers, which were not necessarily positive, but offered a more holistic perspective.

\section{Asylum Seekers: "Takers Rather than Givers"}

My analysis revealed that asylum seekers were commonly depicted as what Lawlor and Tolley (2017) refer to as "takers rather than givers," supported by news media's significant preoccupation and reporting on the costs associated with managing their unsanctioned entry into the country (p. 972). A few examples include the National Post new article by Forrest (2017a), which reported on the range that the government and its agencies spend on each asylum seeker:

On average, $\$ 15,000$ to $\$ 20,000$ is spent by different levels of government on each asylum claimant, according to Michael MacDonald... of the citizenship and immigration department, though "it very much does vary." (para. 2)

In the Globe and Mail news article by Curry and Zilio (2018), the focus was similarly on the overall cost of asylum seekers to the federal government: "Managing the influx of asylum 
seekers at unauthorized points along Canada's border with the U.S. is on pace to cost Ottawa more than \$1-billion over three years" (para. 1). The article continues with reporting on the cost of each individual asylum seeker:

The average cost for each migrant who entered Canada between border crossings is $\$ 14,321$ for the entire refugee claim process. That figure is predicted to rise to $\$ 16,666 \ldots$ as wait times in the system get longer" (Curry \& Zilio, 2018, para. 2).

Several articles also reported on the costs of temporary housing costs for asylum seekers in urban centres like Toronto (Forrest, 2018b; Warnica, 2018b; Grant, 2018). Overall, in this collection of news media coverage that fixated on the asylum seekers to the government, the numbers (seemingly high in quantity) were largely decontextualized; it is unclear how the costs are relative to spends in the immigration system at large.

Continuing with the trend of presenting asylum seekers as "takers," few articles referred to the skills or occupations that individual asylum seekers may have held in the U.S. (or in their country of origin in the cases they had used the U.S. as a thoroughfare to Canada). Much like in the existing literature, asylum seekers were not portrayed as potential "givers" with human capital to contribute or offer to Canadian society. This narrative was further perpetuated by politicians, especially the federal Conservative opposition. This was made clear in the National Post news article by Forrest (2017a) in which a government official reported that work permits for asylum seekers in Quebec were being expedited: "The idea is to help people get into the workforce quicker" (Forrest, 2017a, para. 9). This invoked criticism from Conservative immigration critic Michelle Rempel, who felt expediting work permits "sends the wrong message" (Forrest, 2017a, para. 11). Rempel's opinion was that the government should instead 
focus on enacting measures so that "people are playing by the rules [and] enter the country legally" rather than incentivizing people to "enter the country illegally" (Forrest, 2017a, para. 11). This is an example of the paradoxical framing of asylum seekers as drains on the economy while also unworthy of the chance to work to support themselves and contribute to Canada.

\section{The "Us" Versus "Them" Division}

In keeping with asylum seekers being referred to as "takers rather than givers," my analysis revealed the common use of representational strategies that fuel the "us" versus "them" division (Lawlor \& Tolley. 2017). This leads to asylum seekers being "othered" by reporting, constructed as "them" in opposition of "us," which is ostensibly Canadians and/or the Canadian public (Richardson, 2007). According to van Dijk (1993), such news coverage "aligns [social actors] alongside or against particular ideas" (as cited by Machin \& Mayr, 2012, p. 78). Additionally, the representation of social actors in opposition to one another is what van Dijk (1993) refers to as "ideological squaring," achieved by presenting both in an oversimplified manner (Machin \& Mayr, 2012, p. 78).

In the National Post news article by Warnica (2018), the focus was on the volume of people in Toronto's emergency shelters. The article reported that city personnel and resources were at capacity, "no longer [able to] accommodate new refugee or asylum seekers" (para. 1). Toronto Mayor John Tory was quoted throughout the article; he shared at the time that if more claimants were sent to the city, it would require the conversion of community centres into shelters to accommodate them, leading to the cancellation of public programs (Warnica, 2018). This is an example of how asylum seekers are framed in opposition to Torontonians for the programs and services that the latter are entitled to. This paired with a focus on the costs of 
asylum seekers leads to the perception that they are the problem, creating a hierarchy between them and Toronto residents that frames the latter as worse off because of asylum seekers (Lawlor \& Tolley, 2017).

The "us" versus "them" narrative was also present in the way that the Manitoba town of Emerson and its residents were depicted in the National Post news article by Quan (2017). The opening sentence reads "Residents of Emerson, Man., population 700, pride themselves on being a small town with a big heart," implying that the residents are not only charitable, but embody all that a "big heart" symbolizes: love, compassion and generosity (Quan, 2017, para. 1). The journalist went on to report that once it was known that 19 asylum seekers were in need of refuge from "frigid conditions," a local official "didn't hesitate" to allow them in to a temporary emergency shelter (Quan, 2017, para. 1). Paradoxically, the head of the town, Greg Janzen, was directly quoted as saying: "We've had so many people just roaming around in the town of Emerson knocking on people's doors in the middle of the night. People are scared"' (Quan, 2017, para. 4). The journalist then quotes Janzen indirectly as saying that if the town was expected to accommodate the "border jumpers," then they would need support from the CBSA or RCMP, adding "We're not trained to be security" (Quan, 2017, para. 7). This reporting makes clear that safety and security threats are of concern for both residents and members of the local government. The quoted official's sentiments are at odds with the journalist's initial description of the town. Where previously the residents were framed as "generous" and proud to have a "big heart," they were later described as fearful of asylum seekers concealed by the dark of night. Another example of the "us" and "them" division is found in the Globe and Mail news article by Perreaux (2017a), making evident the opposing ways in which asylum seekers and members of 
the Canadian public are framed. Both the headline "Fatigue may have played role in crash that killed Quebec Mountie during border crossings surge," and the first sentence of the article speculate that the "surge" of irregular border crossers "may have" led to fatigue which "may have" led to RCMP Constable Richer Dubuc to crash his vehicle head-on into a tractor, ultimately leading to his tragic death later in hospital. In the article, all five sources quoted shared the contributions Dubuc made to Canadian society, both as an individual and worker. The use of functional honorifics to represent the deceased "Constable Richer Dubuc," and three of the five sources, including "Constable Serge Bilodeau," "Constable Bernard Vandal," and "Dr. Pecko," suggest authority in their respective fields and that they should be allotted "a degree of respect," serving to indicate to the reader the importance of the individuals sourced in the article (Machin \& Mayr, 2012, p. 82). Conversely, asylum seekers were not quoted in the article, granting them little social influence. Whereas asylum seekers are impersonalized and generalized, Dubuc is personalized and individualized. The journalist paints a picture of the person and employee that Dubuc was; someone who "lived in the area" and was therefore part of the community in which he worked (Perreaux, 2017a, para. 9). His widow is quoted as saying that Dubuc "worked a massive amount of overtime during the migrant crisis... he was always eager to help" (Perreaux, 2017a, para. 5). Later in the article, the journalist reports on an incident in which Dubuc and fellow RCMP officers "helped rescue a border crosser who fell into a stream and almost died of hypothermia and diabetic shock" (Perreaux, 2017a, para. 13). Lastly, he is described as a family-oriented, "42-year old father of four"; all of which contributes to the framing of a hardworking, heroic, and selfless person who put his work before himself. 
The journalist's choice to employ representational strategies of personalization, individualization, and specification to describe Dubuc implies a particular meaning that emphasizes his position as "one of us," someone who was not only a member of the community in which he lived, but someone who represented Canadian values of family and dedication to his work (Machin \& Mayr, 2012, p. 78). Dubuc is effectively being evaluated through the representational strategies employed by the journalist, which will later be interpreted by the reader (Machin \& Mayr, 2012). In this way, both social actors (Dubuc and the anonymous asylum seekers) are represented in opposing ways, which can contribute to the cause of his death being oversimplified (Machin \& Mayr, 2012). Paired with the emphasis of his role as an RCMP officer, these representational strategies contribute to the overall perception that Dubuc was simply doing his job to reinforce Canadian sovereignty through its territorial borders. Indeed, in the simplest of terms, nationalist ideology is expressed through a nation's borders, and the maintenance of territorial borders is a nation's primary motivation (Sutherland \& Roszko, 2012). Meanwhile, the asylum seekers are represented in an impersonalized manner, collectivized in a way that frames them as threatening valuable members of Canadian society like Dubuc.

\section{Dehumanization}

The example cited above by Perreaux (2017a) is also an example of representational strategies employed by journalists that dehumanize asylum seekers. Representational strategies refer to the "semiotic choices" taken by the journalist in their effort to depict social actors (Fairclough, 2003, p. 145; van Leeuwen, 2008). Machin and Mayr (2012) argue there are no "neutral" ways to depict people (p. 77). The most prominent representational strategies used to depict asylum seekers found in my analysis were aggregation and functionalization (van 
Leeuwen, 2008). Through these choices, asylum seekers were habitually constructed by news media in homogenous ways: one large group which shared primarily negative "characteristics, backgrounds, intentions, and motivations," effectively serving to "reduce these groups to their functions" as entrants and arrivals at the Canadian border (KhosraviNik, 2010).

The process of aggregation quantifies social actors in a way that depicts them as statistics (Machin \& Mayr, 2012). van Dijk (1991) adds that this representation strategy is often employed to "give the impression of objective research and scientific credibility" when in reality, it glosses over specific figures and numbers (as cited by Machin \& Mayr, 2012). A few examples of articles that employed aggregation include:

"The same questions, or similar, are being asked by thousands [emphasis added] of other asylum seekers who have fled across the border into Canada from the U.S...." (Forrest, 2017b, para. 2)

"We are talking, after all, about an awful lot of potential border-crossers - perhaps 11 million [emphasis added] people are in the U.S. illegally." (Selley, 2017a, para. 6) "Irregular or illegal? The fight over what to call the thousands [emphasis added] of migrants streaming into Canada." (Hopper, 2018) "Minutes later, they will walk into Canada unsupervised, joining hundreds [emphasis added] of African migrants who have fled north from the U.S. this year." (Giovannetti, 2017a, para. 1)

"What was Mr. Trudeau thinking when he chose to use the r-word last week in rebuking a Quebec heckler calling on him to reimburse... the cost of processing and housing thousands 
[emphasis added] of "illegal immigrants" who have crossed the border..." (Yakabuski, 2018, para. 4)

This process of aggregation serves to depict asylum seekers as a collective, unanimous, and homogenous group in which their individual identities are "strategically backgrounded" (KhosraviNik, 2010, p. 13).

My analysis also found the common use of metaphors for large quantities. Of significance were words such as "flood," "wave," and "overflow." Some examples include: "What has Ottawa got in place to deal with a flood of humanity [emphasis added] probing the world's longest unprotected border?” (The Globe and Mail, 2017, para. 10) "The Liberal government looks set to be swept up by a second wave of illegal asylum seekers [emphasis added] along the Quebec border...” (Ivision, 2017, para. 6) "Toronto has been filling up with the overflow of refugee claimants [emphasis added].... Unable to deal with the continuing flood crossing the border [emphasis added] from the U.S., Quebec closed off its shelter system to new refugee claimants in April.” (McParland, 2018, para. 7)

"In the past few years this trickle of asylum-seekers has turned into a flood [emphasis added], thanks to Facebook and other modern communication networks." (Wente, 2018, para. 7)

My analysis is in line with that of Van der Valk (2003) who found the metaphor of water has commonly been used to frame the immigration system as under threat and out of control. Indeed, a flood is an overflow of a body of water onto land with ruinous potential. These metaphors liken 
asylum seekers to inclement weather that threaten to overtake the country, implying that they will have an overwhelming and damaging impact (Abid, Manan, \& Rahman, 2017).

My analysis also found that several articles referred to asylum seekers as "border jumpers," including the National Post opinion article by Ivision (2018) and the Globe and Mail news article by Andrew-Gee (2017). Meanwhile, Selley (2017a) described asylum seekers as "jumping the queue," problematizing the asylum seekers rather than the system itself which facilitates their entrance (para. 23). The metaphorical description of asylum seekers as "jumpers" or as "jumping" reflects the representational strategy of functionalization that depicts people in terms of their actions or functional role and can have a dehumanizing effect (Machin \& Mayr, 2012). "Jumping" implies that asylum seekers are literally leaping or propelling themselves through the air over the Canada-U.S. border. The descriptor implies first that the border is a tactile barrier or wall that can be jumped over, when in truth, the Canada-U.S. border between ports of entry is virtually invisible and easily crossed. Describing asylum seekers as "jumpers" implies that they possess superhuman strength and physical traits to invade Canadian territory. I found this was further augmented by coverage that more explicitly framed asylum seekers as "sneaking in" or "gaming" the system, implying them as concealing nefarious motives (Quan, 2017, para. 1; Yakabuski, 2018, para. 6). Furthermore, this narrative also illegalizes asylum seekers, when in truth, individuals who believe they have a well-founded fear of persecution are legally permitted to make a claim for asylum under international treaties once on Canadian territory. Overall these kinds of representational strategies that dehumanize asylum seekers ignite the discourse of moral panic and were prevalent in my data set. 


\section{Compromised Canadian Systems}

In keeping with the characterization of asylum seekers as active agents possessing the necessary skills to unlawfully invade Canada's borders was the representation of the Canadian immigration system as compromised. Key elements of the immigration system like the Canada-United States Safe Third Country Agreement and Canada-U.S. border were framed as ineffectual in oversimplified terms. The Agreement's criteria that facilitates the entrance of asylum seekers between ports of entry was often framed as a "loophole," as in the case of the aforementioned Globe and Mail opinion article by Wente (2018): "The root of the matter is a gaping loophole [emphasis added] in the Canada-U.S. Safe Third Country Agreement, which does not allow people arriving from the U.S. to claim protection at an official Canadian port of entry" (para. 6). I argue this statement vastly oversimplifies the situation, implying that the Agreement was carelessly employed by both governments. In addition, the reporting of suggestions from federal opposition parties—including the NDP's suggestion to suspend the Agreement entirely, or the Conservative's suggestion to declare the entire border an official entry point — were often not accompanied by journalist's explanations of the actual implications of either suggestion.

There were some articles that did well to dive into both suggestions. This was achieved by careful reporting of the geopolitical complexities and interconnected relationship between Canada and its southern neighbour, especially in the era of President Trump and delicate trade relations between the two countries. Given the Trump administration's "crackdown" of non-sanctioned migration, these articles acknowledged the grim reality in which the Trump 
administration is likely to be unperturbed by asylum seekers who leave its territory in order to seek asylum in Canada. The Globe and Mail's opinion article by Clark (2017) conceded:

But the Americans don't want to close [the Safe Third Country Agreement]. They don't want to go through a lot of trouble to stop migrants from leaving the U.S. It's time to stop thinking there are easy, wave-of-the-pen solutions for Canada's border problem. (para. 3) The article goes on to state it is unlikely the U.S. administration would agree to "help [Canada] with migrant flows by taking people off their hands" (para. 7). Clark (2018) penned another article in 2018 which further elaborated on the complexities, stating that "the U.S. can tear up the whole agreement without even flinching" (para. 7).

Only a few articles revealed that former Prime Minister Stephen Harper's government had previously attempted to request that the U.S. government to change the terms of the Agreement, but the Obama administration had declined (Clark, 2018). The National Post's opinion article by Ivison (2017) did so, reporting that "The request [to close the loophole in the Safe Third Country Agreement] was refused, in part... because the U.S. sees it [as] an avenue for illegal aliens to deport themselves" (para. 14). The aforementioned National Post opinion article by Coyne (2018) also stated: "Negotiated by the Chretien government in the aftermath of the Sept. 11 attacks, it was essentially a favour to us, part of a larger package of border measures; Canada had indeed been seeking such an agreement for years" (para. 8). These few articles did well to clarify just how complex Canada-U.S. relations are, and how reliant Canada is on the U.S. to make changes to the agreements and treaties that govern the flow of asylum seekers. Additionally, my analysis found that very few articles took the time to contextualize a critical piece of the puzzle: the true nature of the 8,891 kilometre Canada-U.S. border (the 
longest international border in the world) (Government of Canada, 2018). I gather this information is largely unknown to Canadians who do not live along the border, perhaps in part due to the orderly way in which most are obligated to cross over into the U.S. In reality, between the predetermined ports of entry for crossings, much of the Canada-U.S. border is unguarded. Coyne (2018) explains this key context:

So far as the border goes undefended by Canada, it is because it is, as far as we are concerned, indefensible. We simply don't have the resources to patrol an eight-thousand-kilometre border...” (para. 3)

In the Globe and Mail opinion article by Keller (2018), similar context is provided:

For most of the planet, Canada is just about the hardest place on earth to get to. But for someone already in the U.S., Canada is an absurdly easy destination... At a thousand points along the world's longest undefended border, an unauthorized journey... is as simple as taking a taxi... then walking across a field or stepping across a road. (para. 5)

These two examples do well to provide fundamentally important context to understanding this very complex situation. Indeed, not only would guarding the entire stretch require an immense amount of resources, it would require entirely new regulations to be created between the two countries (Clark, 2018). Overall, my analysis found that the characterization of the Canadian immigration system as compromised was done so in oversimplified terms, with only a handful of articles taking the time to explain the real geopolitical considerations and complexities.

\section{Limitations of the Global Immigration Regime}

My analysis also found that the overarching problematization of asylum seekers was largely achieved through the exclusion of discussion about the fundamental limitations of the 
global immigration regime at large. None of the articles spoke to the limited number of opportunities that people in the Global South have to migrate to more prosperous Global North countries unless they fall into very specific categories. Moreover, that Canada's immigration policy within a neoliberal framework is highly regulated, and prioritizes the entrance of immigrants that largely serve the economic needs of the nation (Huot et al., 2016; Root et al., 2014; Arat-Koç, 2012). This broadly means that there are two major pathways to immigration: highly-skilled migrants who are perceived as potential assets and contributors to the economic growth of the nation, and low-skilled workers who can migrate in order to fulfil labour shortages at low wages, but who face barriers towards permanent settlement (Root et al., 2014). Generally speaking, those who do not fall into these categories (or have family members already in the country to facilitate their entry,) have limited opportunities to immigrate to Canada. The admission of refugees under the Convention presents a third and different option for those facing specific forces like war, violence, or persecution (UNHCR, 2010). In the National Post's opinion article by Selley (2017a), an asylum seeker is quoted to underscore this point:

There are people, like Omar, who claim they always intended to come to Canada. "I spent several years in Saudi Arabia, but you will never get legal status there," he told La Presse. "It's impossible to make a living." He will have to prove a fear of persecution in Yemen, not just of penury [emphasis added], to gain refugee status. (para. 6) This is indeed true, a migrant who left their country of origin because of penury (extreme poverty) in search of better economic opportunities does not fit under the category of a refugee, and Canada may very well evaluate that their claim for refuge is ineligible. Selley (2017a) is one of several columnists from both the Globe and Mail and the National Post who speculated that 
among those who crossing between ports of entry, some may not legitimately be refugees or deserving of refuge in Canada. The National Post opinion article by McParland (2018) states: "The fact [that] many of the recent claimants are not refugees, but economic migrants seeking to exploit a weakness in Canada's generous border rules, is largely being overlooked" (para. 10). In the Globe and Mail opinion article by Wente (2018), she uses quotation marks around "refugees," inferring that they are not legitimately so (para. 7). While it is indeed true that asylum claims must first be evaluated and only granted to those who can prove they are facing war, violence, and persecution, Wente (2018) continues with the following unsubstantiated claim: "But many, if not most, are clearly economic migrants [emphasis added] whose chance of obtaining immigration status is low."

While this may indeed be true that some of the asylum seekers who crossed between ports of entry may not fit into the criteria of a refugee, my analysis found what was missing from the coverage was that important inclusion of the fundamental limitations of the global immigration regime in which only very specific populations under distinct pathways are eligible to migrate from the Global South to Global North countries like Canada. The exclusion of these factors in the coverage fails to call attention to the realities of the twenty-first century in which there will be more factors leading to the forcible migration of people. This includes, but is not limited to, disaster-related displacement caused by extreme weather events that have become more common with a changing climate (UNHCR, n.d.; Missirian \& Schlenker, 2017). While news media has coined these individuals "climate refugees," the UNHCR (n.d.) reports that this is largely a misnomer because these individuals do not meet the Convention criteria under international law. And while disaster-related conditions, like drought-related famine, are 
commonly linked to situations involving armed conflict and violence, it remains that there will increasingly be more people who may not be facing persecution but seek better living conditions and economic opportunities (Missirian \& Schlenker, 2017). Taking these factors into consideration, my analysis shows that news media more commonly framed asylum seekers as the problem rather than the geopolitical factors that result in forced migration (Philo et al., 2013). Moreover, largely excluded was any discussion of the socioeconomic disparities between the Global North and the Global South, as well as the systemic inequalities and fundamental limitations within the global immigration regime that impact the lives of individuals.

\section{Individualization, Personalization, and Perspective}

My analysis found that a small number of articles employed representational strategies that humanized asylum seekers, which specifically represented their perspectives, stories, and voices directly. According to Reisgl and Wodak (2001), the characterizations used to depict a person have "psychological, social, and political purposes for [both] the writer and the reader" (p. 47). In other words, the depiction of a person's actions play a key role in reflecting back how they are positioned in relation to larger ideologies. This small set of articles were not necessarily complimentary about asylum seekers or the situation at large, but offered more balanced perspectives. In some cases, this was through the inclusion of individualized and personalized portrayals. In others, the focus was on the potential "means and opportunities" that Canada, one of the world's wealthiest countries, may have to contribute to a solution required to support asylum seeking people overall (van Dijk, 1996, as cited by Wodak, 2001, p. 1).

In the Globe and Mail news article by Grant (2018), several asylum seekers were featured with personalized narratives: "He's now living alone at a shelter in Toronto, and can't sleep at 
night because he worries about his family, who have gone into hiding" (para 1). Later in the same article, Grant (2018) tells the story of an asylum seeker and his partner, a trans woman:

Several factors spurred their decision to leave their home country... a string of brutal murders of gay men there for which the perpetrators were not convicted; threats and discrimination from family, landlords, co-workers, and employers; and, one day, watching a YouTube video of Justin Trudeau, dancing in a Pride Parade. (para. 29)

In another article, Quan (2017) indirectly quotes an asylum seeker who was living in the U.S. for four years without receiving refugee status: "He was worried about getting deported... So he paid a smuggler $\$ 500$ in Minneapolis to drive him close to the border... and then walked five hours in the snow before he got picked up by police." He was then directly quoted as saying: “I'm not safe anymore in the U.S." (para. 23). In Forrest's (2017b), she directly quotes an asylum-seeker from Haiti: "'I hope one day, God will let me see my husband again,' she said, speaking in French, her five-month-old son, Joshua, sleeping in a stroller beside her" (para. 10). By detailing the stories of asylum seekers with personalized accounts about their lives and the struggles they endured which led them to Canada, these journalists have employed representational strategies that individualize asylum seekers. This can work towards evoking a sense of empathy within the reader (Machin \& Mayr, 2012). A man who lies awake at night worrying about his family and a French-speaking mother missing her husband with her baby sleeping next to her are people we can see in ourselves, our family members, and our friends. Watching a YouTube video is a common activity many Canadians engage in. Meanwhile, the illustration of Trudeau "dancing in the Pride Parade" speaks to idealized Canadian values of inclusion of people with diverse sexual orientations, gender expressions, and gender identities. 
Overall, these personalized portrayals serve to humanize asylum seekers as individuals that readers can relate to (Machin \& Mayr, 2012).

In another news article by the Globe and Mail's Perreaux (2017b), the journalist depicts a Syrian family arriving on Roxham Road in New York state to cross into Quebec:

Raed Alakhras, his wife and four very young children, hopped out of a taxi and put one of their smaller children in a stroller and strapped a baby carrier onto Mr. Alakhras's chest for the youngest. The Syrian family travelled from Saudi Arabia to the U.S. last week, but their final destination was always Canada. Mr. Alakhras, an accountant, was working in Saudi Arabia on a contract that expired. He wasn't going to be allowed to stay and he was not going back to Syria, he said. (para 25)

The representational strategy of personalization and individualization is significant in this article and mirrors the same discourse employed in Perreaux's (2017a) article regarding RCMP Constable Dubuc. The choice to include personalized and individualized details effectively brings the reader closer to the social actors (Machin \& Mayr, 2012). The positive individualized portrait of a man strapping a baby carrier to his chest frame him as a family-oriented father who is hardworking (an accountant, no less) who had no choice but to cross into Canada between ports of entry in order to keep his family safe. The journalist's choice to emphasize his role as a parent has an implied meaning that he is "one of us," allowing readers to foster a sense of compassion for asylum seekers who they may otherwise regard in a negative light (Machin \& Mayr, 2012). In other words, the deployment of personalization in these articles allows the reader to see themselves reflected in the stories and contextualize asylum seekers in the overall 
global crises that have forced them to seek refuge. In these cases, the countries of origin (and the U.S. government) are framed as prejudicial forces while Canada is framed as a place of refuge.

\section{Idealized and Inclusive Canada}

In step with articles that framed Canada as a safe haven for those in need, my analysis identified a small collection of articles that employed nationalistic themes of Canadian exceptionalism and generosity. In effect, asylum seekers were represented as an opportunity for Canadians to fulfil its humanitarian duty. The Globe and Mail opinion article by Mason (2018) is notably titled "Migrants dying at sea used to spark outrage. So what's changed?", speaking to the moral obligation that Canada has to help the world's most vulnerable. Mason (2018) writes:

Polls in recent years have offered conflicting pictures of just how supportive Canadians are of current immigration levels and the plight of asylum seekers. The situation here is nothing like the one that many parts of Europe have witnessed... Were this country ever to be faced with the massive influx of refugees... attitudes could shift... in an instant. It wasn't that long ago that hundreds of migrants dying at sea sparked mass outrage, including in this country. It doesn't today, and we can only wonder why. (para $14 \& 15$ ) In the Globe and Mail opinion article by Ibbitson (2018) titled "Can one of the nicest places in the world - Canada — survive what's to come?", the author frames the article around that very question of whether or not Canadians will live up to its reputation of "niceness" and inclusion. He argues that Canada is not immune to the rise in populism present in other Western democracies, but there are signals that irregular migration could change that:

In recent decades, Canada has sloughed off its chronic insecurity and sense of inferiority, celebrating the diverse, tolerant society we have become. But confidence can devolve 
into complacency. Our commitments to high rates of immigration, to multicultural accommodation, to respect each for the other, to a free and open society are about to be tested. On the nation's 151st birthday, let's resolve to pass that test. (para $15 \& 16$ )

In the article by Forrest (2017b), a local resident in Cornwall, Ontario is directly quoted, speaking of his own family's pathways to Canada via a generous immigration system:

Both my parents are immigrants, immigrated in the 1950s from Italy, and had they not been given this opportunity to live in our country, my brother and sister and I certainly wouldn't be where we are. We wish these people nothing but the best. (para. 30)

Forrest (2017b) has employed the representational strategies of personalization and collectivization by directly quoting this member of the Canadian public to frame asylum seekers as being people who are just "like us." Overall, this collection of articles that are centered around the call for inclusion of those seeking asylum, do well to put into context the larger humanitarian crisis and calling to attention the means Canadians have to support those in need. By offering this perspective, the journalists are asking the reader to explore how the treatment of asylum seekers now will contribute to the kind of country Canada wants to be and will be to future generations.

\section{Limitations}

Given the scope of this research project, I understood that whichever newspapers I selected for inclusion in the data set were ultimately going to pose limitations. In order to compile a rich data set, I opted to compare two daily, English-language newspapers with a similar national focus rather than a popular paper like the Toronto Star. Given that both the Globe and Mail and National Post have right-of-centre ideologies, I understood that the decision 
to focus solely on these two papers might reveal a moderately conservative bias (Van Zandt, 2018). I acknowledge that by selecting these two papers, I have excluded newspapers with left-of-centre ideologies that may represent more liberalized views on migration.

Another limitation is that I did not analyse headlines separately from the articles in full. Research from Steuter and Willis (2009) found that a significant portion of the population scan news headlines rather than reading the articles in full, which means they represent a "primary source of condensed information" (p. 13). This is backed by the aforementioned Angus Reid Institute (2018) results in which 20 per cent of the participants answered that they got their news on asylum seekers from "just scanning the headlines." Given this, I acknowledge that a dedicated focus on news headlines could be useful to understand how asylum seekers are framed in just that short synopsis. Given headlines influence the interpretations by readers of social actors, they are "ideologically powerful" and a common way in which readers process information, thereby warranting an entire study of headlines themselves (Steuter \& Willis, 2009, p. 13). The scope of this research project did not allow for an in depth focus on headlines, rather I examined the articles themselves. In addition, some critics of discourse analysis believe there are limitations to the critical discourse analysis as a methodology because it represents the analyst's observations and interpretations (Tolley, 2016). As such, I have aimed to provide as much detail as possible on the way in which the data set was selected and choices made. Keeping these limitations in mind, I will now provide a discussion of the implications of my analysis. 


\section{CHAPTER 5}

\section{Discussion and Implications}

This research project has focused on the way that Canadian news media discourse depicts, portrays, and frames asylum seekers who crossed the border between ports of entry into Canada from the U.S. in 2017 and 2018. My analysis of 70 articles from the Globe and Mail and the National Post has revealed that asylum seekers are typically homogenized and collectivized in negative ways that fuel the perception that they are a problem and outsiders, positioned separately from "us," the Canadian public. My findings are in line with what was found in the existing literature which has consistently shown how various migrant groups are similarly constructed in problematizing ways.

Before elaborating on a discussion of the implications of my findings, it is important to reiterate the role of news media from the perspective of critical discourse analysis which has guided my research. News media is part of a system of mass media and plays a critical role in Western democracies: it transmits societal values, myths, and ideologies to readership while simultaneously being informed by these same factors (Richardson, 2007; Henry \& Tator, 2010). News media is the source of people's everyday knowledge, informing their understandings and interpretations of the world around them (van Dijk, 2000; Henry \& Tator, 2010). Indeed, according to van Dijk (2006), mass media influences the "common sense ideologies" which are the bedrock of "underlying foundations of 'truths' about the social world [we] live in and the value system that guide [our] behaviour in it" (as cited by Torkington \& Ribeiro, 2019, p. 23). News media employ representational strategies (discursive choices made to depict social actors) which are then interpreted by the reader (Machin \& Mayr, 2012). Overall, news media discourse 
is not only influenced by the institution and society to which it belongs, but has equally as much influence (Jørgensen \& Phillips, 2002).

Keeping this framework in mind, my analysis found that the problematization of asylum seekers was facilitated through the use of representational strategies that fueled "us" and "them" divisions. Tying back to Said's thesis of Orientalism, "the West" (in this case, the receiving nation of Canada and the Canadian public) is constructed as superior, civilized, and dominant in contrast to the "non-Western other" (asylum seekers entering between ports of entry) that are constructed as "uncivilized, unruly, and lacking in cultural sophistication" (as cited by Kyriakides et al., 2018, p. 61). The implications of these representational strategies by news media are complex and insidious. The lack of individualized and personalized portrayals of groups of people can lead to them to be collectivized and homogenized as a group of distant "others" mutually exclusive from members of the receiving nation (Richardson, 2007). Torkington and Ribeiro (2019) argue that this strategy can figuratively remove asylum seekers from the reader's "world of immediate experience" (p. 27). By framing asylum seekers as a group in competition and incompatible with Canadians, news media effectively creates a hierarchy between the two groups which can lead to a greater preoccupation over what they are perceived to be taking rather than contributing (Machin \& Mayr, 2012; Berry et al., 2015; Lawlor \& Tolley, 2017). This kind of discourse, paired with the fixation on the cost of asylum seekers to the government in largely decontextualized quantities, means that news media has foregrounded the potential talents and social capital each individual brings with them (Lawlor \& Tolley, 2017). Moreover, rather than being portrayed as resilient and determined individuals who are fighting and deserving of better lives, they are framed as burdens. All of which fuels the 
portrayal of asylum seekers as a problem; people perceived as not having much to offer Canadian society.

My analysis found that the problematization of asylum seekers was further enforced by discursive representations that illegalized and dehumanized them. Asylum seekers were commonly framed as successfully undermining, tricking, and threatening weakened Canadian institutions. The implication of these discursive representations is that doubt is cast on the integrity of government institutions and immigration systems, fueling apprehension and anxiety about the future (Atak, 2018; Hynie, 2018). As per Atak (2018), the control of migrants entering into countries in the Global North without its government's "legal permission" augments the perception that they are a "threat to national sovereignty and security, as well as public welfare and the integrity of [the country's] immigration and refugee systems" (p. 176). Moreover, given the habitual practice of framing non-White migrants with their association to "terrorism, crime and unemployment" in a post-9/11 world, this kind of discourse heightens the perception that migrants threaten national security, national identity, social cohesion, and the economy (Cheong, Edwards, Goulbourne, \& Solomos, 2007, p. 34; Every, 2006). This plays into van Dijk’s (2000) assessment that the framing of marginalized individuals as "active agents" in situations where their actions are perceived as "bad" can fuel negative perceptions of them by readers (as cited by Machin \& Mayr, 2012, p. 105).

The representational strategy of quantifying groups of people, treating them as statistics rather than individuals, can also lead to a "fear by numbers" to be activated, representing the discourse of moral panic (van Leeuwen, 2008, p. 38). While it is likely that readers rationally know that news media employ metaphors rather than literally describing what is occuring, 
according to van Gorp (2007), equating asylum seekers to inclement weather or pests can "activate a schema on the part of the reader, who... cognitively associate[s] a chain of 'reasoning devices' which [while] are not necessarily explicitly present in the text, lead to the overall frame" and negative interpretation of the situation (as cited by Torkington \& Ribeiro, 2019, p. 27). The implications of these representational strategies are that asylum seekers are framed as "inhuman" by news media, which can lead to them being perceived as "explicitly and fundamentally unworthy of the protection of the law" (Sheth, 2009, p. 53). This in turn can augment and justify the lack of support, social inclusion, and legal protection that asylum seekers are entitled to in Canadian society under international treaties (Kaiser Ortiz, 2019, p. 190).

Critical discourse analysis also assumes that news media is not neutral or objective, nor does it lend an equal amount of attention, bandwidth, and social influence to all groups (Henry \& Tator, 2010). According to Portin (2015), "one of the trends in print media is that refugees and asylum seekers' own voices, views and opinions are almost systematically neglected" (p. 2). In line with these sentiments, my analysis revealed that asylum seekers were not often directly quoted or sourced, giving them little social influence, whereas Canadian social actors were often given prominence and stature, often sharing detailed viewpoints and perspectives. Out of 35 articles from each paper, only three of the National Post articles directly quoted asylum seekers (Forrest, 2017b; Selley, 2017a; Selley, 2017b), while the Globe and Mail featured only five (Perreaux, 2017a; Giovannetti, 2017a; Perreaux, 2017b; Giovannetti, 2017b; Mason, 2017). In several news media articles, Canadian sources were conversely personalized and characterized as giving of themselves and their communities. This aligns with the findings in the literature that showed how news media commonly uses binary representations that frames members of the 
receiving nation as heroic, generous, and dutiful (Cartner, 2009). While my analysis found that some news media coverage shared personalized narratives from asylum seekers, they were less common. The implications of this imbalance in news media coverage means that the plight of asylum seekers and those seeking refuge is deemphasized, leading to the perception that Canadians are the most negatively impacted while also obscuring the major humanitarian crises in which asylum seekers are forcibly displaced from their homes in the first place. I argue that news media has a responsibility to portray asylum seekers and migrants alike as multifaceted individuals much like Canadians, people "with evolving identities, complicated self-narratives, and compounded life stories" that are deserving of compassion (Kaiser Ortiz, 2019, p. 194). Allowing asylum seekers to tell their own stories, rather than depicting them solely from the perspective of those in receiving countries to which they seek entry, can serve to humanize them in order to foster less negative portrayals by news media and subsequent interpretations by readers (Berry et al., 2015; Kaiser Ortiz, 2019).

While my analysis found that news media largely failed to address the individual dimensions of the issue, it also tended to oversimplify and gloss over the systemic dimensions that offer important context to the many reasons as to why asylum seekers may be trying to enter Canada. This issue of asylum seekers crossing between ports of entry into Canada from the U.S. is an incredibly complicated issue. My analysis revealed how news media commonly oversimplified the issues and failed to provide context for key factors like the true nature and complexities of the Canada-U.S. border, geopolitical relations between the two countries, and how much control Canada has of the issue at large. This kind of portrayal can lead to the 
impression that the situation is far less complex than it is in reality, making it seem to the reader as though the issue can be easily solved.

Another key factor that was often deemphasized was the global context of 70.8 million people who have been forcibly displaced from their homes, and the fact that very few end up in Global North countries like Canada. While some articles included a call to action for Canada to liberalize immigration pathways to take in more refugees, most failed to remind readership of the broader context in which few refugees settle in Global North countries. Instead, news media was primarily preoccupied with the problematization of asylum seekers rather than the global immigration regime or humanitarian crises themselves. Indeed, few articles called attention to the fact that besides fleeing war, violence, or persecution, there are and will continue to be additional factors like climate-related disasters, poverty, and a lack of economic opportunities that may motivate people to seek refuge in Canada. My analysis also found that no articles provided critical discussion of the global migration regime which offers few pathways towards upward mobility between Global South and Global North countries for the vast majority of people. Had they chosen to take that perspective, they may have been able to ignite discussion as to whether or not it is reasonable, in a world of deep socioeconomic disparities between the Global South and Global North, that people would want to take advantage of a potential opportunity to come to Canada for better lives. Furthermore, few articles discussed the opportunity that asylum seekers present for Canadians to be a country that is proud to leverage its power and privilege to assist those fleeing the increasingly strict immigration measures in the U.S. (Richardson, 2007). Even fewer articles asked readers to examine what kind of future they envision for Canada. Given the reach and role of news media, I argue that journalists should do 
more to probe that very question in the context of the U.S.'s increasingly isolationist immigration policy changes.

This research project and the use of critical discourse analysis has aimed to draw attention to how news media participate in the problematization and dehumanization of people seeking asylum in Canada with the aim to foster more critical engagement with news coverage so that readers can resist and question these characterizations (Kaiser Ortiz, 2019). While the scope of this research project has not allowed for policy recommendations, I do ask that news media and journalists alike work towards examining its coverage of asylum seekers and make changes to offer more fair, nuanced, and balanced reporting of this issue and the individuals entangled within a complex system. I argue that the way forward should be a greater commitment to provide more humanizing and contextualized portrayals of asylum seekers, which I argue must involve their greater inclusion and representation in news media reporting as main sources. By allowing asylum seekers to tell their own stories rather than from the perspective of the receiving nation, more personalized and individualized representations can be achieved (Berry et al., 2015; Kaiser Ortiz, 2019). Next, by contextualizing asylum seekers within larger, complex, and multifaceted systems, news media can offer better analysis of the systemic barriers which limit the opportunities of many in the Global South. Overall, this research project has shone light on the kind of discourse that largely problematizes asylum seekers in an effort to make a case for a more critical approach for news producers and readers alike. I believe that through these acts of inquiry and resistance, asylum seekers can more accurately be framed as human beings who deserve more considerate and careful portrayals by powerful news media institutions (Kaiser Ortiz, 2019). 


\section{Recommendations for Future Research}

I suggest that additional research could be devoted towards a more comprehensive, qualitative study to analyse news media while measuring reader's opinions of asylum seekers. Second, a broader analysis of other newspapers, including the Toronto Star (which is Canada's more ideologically left-of-centre newspaper that has more pro-immigration and pro-refugee narratives) to provide a more holistic data set of Canadian news media coverage on the topic. Moreover, analysis of news media coverage by regional dailies including the Montreal Gazette (near to the main sites of entry between ports of entry by asylum seekers from the United States) could offer even richer data.

\section{Conclusion}

This research project began with an overview and background of the world we now live in, one in which there has been a significant rise in the number of people being forcibly displaced from their homes. I provided some critical context which explains just how few migrants from the Global South end up in Global North countries like Canada. I then offered the geopolitical context in which asylum seekers have been entering Canada between ports of entry, which resulted in significant media attention in 2017 and 2018 on the topic. In chapter 2, I presented an overview of the existing literature which similarly focused on news media analysis in Western democracies, offering major themes and trends found in the literature. With that as a basis of my own analysis, I outlined the importance of my chosen methodology and the way in which I compiled a data set of 70 articles from two, English-language, national newspapers. In chapter 4, I went on to offer my own analysis of the texts I analysed. I elaborated on findings that demonstrate how Canadian national news media primarily problematizes asylum seekers by 
employing representation strategies that dehumanize and decontextualize them. I also provided an overview of a collection of articles which framed asylum seekers in more humanizing ways, and others that had larger humanitarian themes that rightfully called attention to the complexity of the situation and offered more compassionate viewpoints. I then offered a discussion of the potential implications of the findings, with suggestions for how news media can offer more fair and balanced coverage of the topic. 


\section{Appendix A: Data Set}

\section{The Globe and Mail}

\section{Editorial Articles.}

The Globe and Mail. (2017, February 21). Globe editorial: Is Canada ready for Donald Trump's refugee crisis? The Globe and Mail. Retrieved from https://www.theglobeandmail.com/opinion/editorials/globe-editorial-is-canada-ready-for-donaldtrumps-refugee-crisis/article34104802/

The Globe and Mail. (2017, August 16). Globe editorial: Time to fix our uniquely Canadian border mess. The Globe and Mail. Retrieved from https://www.theglobeandmail.com/opinion/editorials/globe-editorial-time-to-fix-our-uniquely-ca nadian-border-mess/article36004741/

The Globe and Mail. (2018, July 18). Globe editorial: The last thing Canada's border needs is another cop. The Globe and Mail. Retrieved from https://www.theglobeandmail.com/opinion/editorials/article-globe-editorial-the-last-thing-canada s-border-needs-is-another-cop/

\section{News Articles.}

Andrew-Gee, E. (2017, May 31). With asylum seeker's reported death, Canada-U.S. crossing debate intensifies. The Globe and Mail. Retrieved from https://www.theglobeandmail.com/news/national/with-asylum-seekers-reported-death-canada-us -crossing-debate-intensifies/article35171898/

Curry, B. and Zilio, M. (2018, November 29). Ottawa on pace to spend more than \$1-billion over three years on unauthorized border crossings: watchdog. The Globe and Mail. Retrieved from https://www.theglobeandmail.com/politics/article-ottawa-on-pace-to-spend-400-million-next-yea r-on-border-crossings/

Dhillon, S. (2017, February 15). Two arrested in Surrey, B.C. after alleged illegal border crossing. The Globe and Mail. Retrieved from https://www.theglobeandmail.com/news/british-columbia/two-arrested-in-surrey-bc-after-alleged -illegal-border-crossing/article34042336

Fife, R. and Zilio, M. (2018, May 17). Travel delays expected as customs agents being moved from GTA to Quebec to handle migrant surge. The Globe and Mail. Retrieved from https://www.theglobeandmail.com/politics/article-customs-agents-moved-from-gta-to-quebec-bo rder-to-handle-migrant-surge/

Giovannetti, J. (2017, February 19). Influx of refugees fleeing U.S. is putting Ottawa to the test. The Globe and Mail. Retrieved from 
https://www.theglobeandmail.com/news/national/influx-of-refugees-fleeing-us-are-putting-ottaw a-to-the-test/article34087595

Giovannetti, J. (2017, February 24). Following the Midwest Passage: Asylum seekers take a cold journey to Manitoba via Trump's America. The Globe and Mail. Retrieved from https://www.theglobeandmail.com/news/national/asylum-seekers-on-a-cold-journey-to-manitoba /article34126957/

Gray, J. (2018, May 23). Toronto converts two community college dorms into refugee centres temporarily for summer. The Globe and Mail. Retrieved from https://www.theglobeandmail.com/canada/toronto/article-toronto-converts-two-community-colle ge-dorms-into-refugee-centres

Hauen, J. (2018, July 30). As Toronto struggles to find space for asylum seekers, other municipalities volunteer to help. The Globe and Mail. Retrieved from https://www.theglobeandmail.com/canada/toronto/article-as-toronto-struggles-to-find-space-forasylum-seekers-other/

LeBlanc, D. (2017, March 2). RCMP not charging asylum seekers for illegal entry into Canada. The Globe and Mail. Retrieved from https://www.theglobeandmail.com/news/politics/rcmp-not-charging-asylum-seekers-for-illegal-e ntry-into-canada/article34183890

Mason, G. (2018, May 17). Manitoba Premier Pallister calls on Trudeau to raise asylum issue with Trump. The Globe and Mail. Retrieved from https://www.theglobeandmail.com/news/national/manitoba-premier-pallister-says-trump-immigr ation-policies-contradict-us-history/article34307116

McCarthy, S. (2017, February 20). Sizable minority says Canada is accepting too many refugees: poll. The Globe and Mail. Retrieved from https://www.theglobeandmail.com/news/politics/sizable-minority-says-canada-is-accepting-toomany-refugees-poll/article34087415/

Peritz, I. (2017, August 22). Immigration Minister denies that Canada was unprepared for surge of asylum seekers. The Globe and Mail. Retrieved from https://www.theglobeandmail.com/news/national/ottawa-denies-being-unprepared-for-surge-of-a sylum-seekers/article36063067/

Perreaux, L. (2017, August 3). Quebec's resources wear thin as wave of asylum seekers swells. The Globe and Mail. Retrieved from https:/www.theglobeandmail.com/news/national/quebec-dealing-with-150-asylum-requests-a-da y-immigration-minister/article35871581/

Perreaux, L. (2017, August 6). False information sends asylum-seeking Haitians to Canada. The Globe and Mail. Retrieved from https://www.theglobeandmail.com/news/national/false-information-sends-asylum-seeking-haitia ns-to-canada/article35892255 
Perreaux, L. (2017, December 22). Fatigue may have played role in crash that killed Quebec Mountie during border crossings surge. The Globe and Mail. Retrieved from https://www.theglobeandmail.com/news/national/fatigue-may-have-played-role-in-crash-that-kill ed-quebec-mountie-during-asylum-surge/article 37418281

Perreaux, L. (2018, April 18). Rift exposed between Quebec, federal government over handling of asylum seekers. The Globe and Mail. Retrieved from https://www.theglobeandmail.com/canada/article-rift-exposed-between-quebec-federal-governm ent-over-handling-of/

Stone, L. (2018, November 4). Toronto stands by data showing almost 40 per cent of people in shelters are refugee claimants. The Globe and Mail. Retrieved from https://www.theglobeandmail.com/canada/toronto/article-toronto-stands-by-data-showing-almost -40-per-cent-of-people-in/

Woo, A. (2017, April 19). RCMP charge Saskatchewan woman with human smuggling. The Globe and Mail. Retrieved from https://www.theglobeandmail.com/news/national/rcmp-charge-saskatchewan-women-with-huma n-smuggling/article34755045/

Zilio, M. (2017, September 14). Canadians divided on granting entry to asylum seekers from U.S., poll finds. The Globe and Mail. Retrieved from https://www.theglobeandmail.com/news/politics/canadians-divided-on-granting-entry-to-asylumseekers-from-us-poll-finds/article36275454/

Zilio, M. (2018, May 1). Canada in 'exploratory' talks with U.S. over border agreement on asylum seekers. The Globe and Mail. Retrieved from https://www.theglobeandmail.com/politics/article-canada-in-exploratory-talks-with-us-over-bord er-agreement-on/

Zilio, M. (2018, May 24). Immigration Minister declines to say whether Ottawa will seek power to turn away U.S. border-crossers. The Globe and Mail. Retrieved from https://www.theglobeandmail.com/politics/article-immigration-minister-declines-to-say-whetherottawa-will-seek-power-to

Grant, T. (2018, June 20). Wave of asylum seekers floods Toronto's shelters. The Globe and Mail. Retrieved from https://www.theglobeandmail.com/canada/article-in-toronto-asylum-seekers-hope-to-carve-out-a -new-home/

Zilio, M. (2018, July 16). Immigration committee to hold summer hearings on asylum seekers. The Globe and Mail. Retrieved from https://www.theglobeandmail.com/politics/article-immigration-committee-to-hold-summer-heari ngs-on-asylum-seekers/

Zilio, M. (2018, September 11). Asylum-seeker surge at Quebec border choking Canada's refugee system, data show. The Globe and Mail. Retrieved from 
https://www.theglobeandmail.com/politics/article-asylum-seeker-surge-at-quebec-border-chokin g-canadas-refugee-system/

\section{Opinion Articles.}

Clark, C. (2017, August 6). There's no easy solution to Canada's border problem. The Globe and Mail. Retrieved from

https://www.theglobeandmail.com/opinion/theres-no-easy-solution-to-canadas-border-problem/a $\underline{\text { rticle35891673/ }}$

Clark, C. (2018, April 26). Declaring entire Canada-U.S. border an official entry point tops Trump's border wall idea for futility. The Globe and Mail. Retrieved from https://www.theglobeandmail.com/politics/article-declaring-entire-canada-us-border-an-officialentry-point-tops-trump/

Ibbitson, J. (2018, June 29). Can one of the nicest places in the world - Canada - survive what's to come? The Globe and Mail. Retrieved from https://www.theglobeandmail.com/opinion/article-can-one-of-the-nicest-places-in-the-world-can ada-survive-whats-to/

Keller, T. (2017, February 23). Canada has never had a real migrant crisis. Trump may have just changed that. The Globe and Mail. Retrieved from https://www.theglobeandmail.com/opinion/canada-has-never-had-a-real-migrant-crisis-trump-ma y-have-just-changed-that/article34120729/

Mason, G. (2018, July 10). Migrants dying at sea used to spark outrage. So what's changed? The Globe and Mail. Retrieved from https://www.theglobeandmail.com/opinion/article-will-europes-migrant-backlash-spread-here/

Saunders, D. (2017, February 25). Canada has a border problem. Here's how to fix it. The Globe and Mail. Retrieved from

https://www.theglobeandmail.com/opinion/canada-has-a-border-problem-heres-how-to-fix-it/arti cle34128651/

Yakabuski, K. (2018, August 22). Something's rotten in Canadian politics. The Globe and Mail. Retrieved from

https://www.theglobeandmail.com/opinion/article-somethings-rotten-in-canadian-politics/

Wente, M. (2018, April 23). Another summer, another border crisis. The Globe and Mail. Retrieved from

https://www.theglobeandmail.com/opinion/article-another-summer-another-border-crisis/ 


\section{The National Post}

\section{Editorial Articles.}

National Post View. (2017, February 24). NP View: Preparing for a border crisis is the most important job the Liberals have now. The National Post. Retrieved from https://nationalpost.com/opinion/national-post-view-preparing-for-a-border-crisis-is-the-most-im portant-job-the-liberals-have-now

National Post View. (2018, June 22). NP View: Canada's no better than America at dealing with immigrants. Just luckier. The National Post. Retrieved from https://nationalpost.com/opinion/np-view-canadas-no-better-than-america-at-dealing-with-immig rants-just-luckier

\section{News Articles.}

Forrest, M. (2017, September 28). More than 32,000 asylum seekers have arrived in Canada so far in 2017. The National Post. Retrieved from

https://nationalpost.com/news/politics/more-than-32000-asylum-seekers-have-arrived-in-canadaso-far-in-2017

Forrest, M. (2017, August 23). 'Will Canada send people back?': Fate uncertain for asylum seekers arriving at tent city. The National Post. Retrieved from https://nationalpost.com/news/politics/will-canada-send-people-back-fate-uncertain-for-asylum-s eekers-arriving-at-tent-city

Forrest, M. (2017, September 6). Dreamers' unlikely to rush to claim asylum in Canada, immigration experts say. The National Post. Retrieved from https://nationalpost.com/news/politics/dreamers-unlikely-to-rush-to-claim-asylum-in-canada-im migration-experts-say

Forrest, M. (2018, July 5). Justin Trudeau and Doug Ford trade barbs on immigration as Ontario says Ottawa should foot the bill for asylum seekers. The National Post. Retrieved from https://nationalpost.com/news/canada/ontario-says-ottawa-should-pay-for-the-mess-caused-by-ill egal-border-crossers?video autoplay=true

Forrest, M. (2018, August 3). Influx of irregular refugees has reached crisis level for most Canadians, poll suggests. The National Post. Retrieved from https://nationalpost.com/news/politics/influx-of-irregular-refugees-has-reached-crisis-level-for-m ost-canadians-poll-suggests?video autoplay=true

Forrest, M. (2018, November 22). Federal government has spent \$2.3M to house asylum seekers in Toronto hotels, some rooms still booked until January. The National Post. Retrieved from

https://nationalpost.com/news/politics/federal-government-has-spent-2-3m-to-house-asylum-see kers-in-toronto-hotels-some-rooms-still-booked-until-january 
Forrest, M. and Humphreys, A. (2018, August 24). Canada's backlogged asylum system is 'not sustainable,' immigration minister says in leaked letter. The National Post. Retrieved from https://nationalpost.com/news/politics/canadas-backlogged-asylum-system-is-not-sustainable-im migration-minister-says-in-leaked-letter?video autoplay=true

Hopper, T. (2018, July 10). Irregular or illegal? The fight over what to call the thousands of migrants streaming into Canada. The National Post. Retrieved from https://nationalpost.com/news/canada/irregular-or-illegal-the-fight-over-what-to-call-the-thousan ds-of-migrants-streaming-into-canada?video autoplay=true

Loewen, C. (2017, August 20). Hundreds of counter-protesters swarm far-right La Meute protest in Quebec City. The National Post. Retrieved from https://nationalpost.com/news/canada/hundreds-of-counter-protesters-swarm-far-right-la-meuteprotest-in-quebec-city

Smith, M.D. (2018, April 3). Trudeau tweet caused influx of refugee inquiries, confusion within government, emails reveal. The National Post. Retrieved from https://nationalpost.com/news/politics/trudeau-tweet-caused-influx-of-refugee-inquiries-confusio $\underline{\text { n-within-government-emails-reveal }}$

Quan, D. (2017, February 7). Manitoba town's generosity is tested amid spike in asylum-seeking 'border jumpers' since Trump elected. The National Post. Retrieved from https://nationalpost.com/news/canada/worried-about-trump-asylum-seekers-braving-the-freezing -prairie-winter-to-walk-into-canada

Quan, D. (2017, February 20). Liberal government 'testing the limits' of Canadians' attitudes to refugees: poll. The National Post. Retrieved from https://nationalpost.com/news/canada/liberal-government-testing-the-limits-of-canadians-attitude s-to-refugees-poll

Quan, D. (2017, March 2). CBSA union president says border is like 'Swiss cheese,' calls for patrol force. The National Post. Retrieved from https://nationalpost.com/news/cbsa-union-president-says-border-is-like-swiss-cheese-calls-for-pa trol-force?video autoplay=true

Quan, D. (2017, May 31). Ghanaian woman found dead near Manitoba border reportedly trying to reunite with daughter. The National Post. Retrieved from https://nationalpost.com/news/canada/ghanaian-woman-found-dead-near-manitoba-border-report edly-trying-to-reunite-with-daughter-in-toronto

Quan, D. (2017, April 20). Husband of Regina woman accused of human smuggling arrested along with another Canadian. The National Post. Retrieved from https://nationalpost.com/news/canada/nigerian-two-canadians-arrested-in-human-smuggling-inve stigation-that-ensnared-saskatchewan-woman

Quan, D. (2018, July 18). Appointment of new border security minister meant to shore up Liberal vulnerability: political observers. The National Post. Retrieved from 
https://nationalpost.com/news/politics/appointment-of-new-border-security-minister-meant-to-sh ore-up-liberal-vulnerability-political-observers?video autoplay=true

Smith, M.D. (2017, August 24). Liberals facing calls for longer-term solution to illegal migration from U.S. The National Post. Retrieved from https://nationalpost.com/news/politics/liberals-facing-calls-for-longer-term-solution-to-illegal-mi gration-from-u-s?video autoplay=true

Warnica, R. (2018, June 26). Toronto faces having to close community centres, cancel programs to house migrant tide from U.S. The National Post. Retrieved from https://nationalpost.com/news/canada/toronto-faces-having-to-close-community-centres-cancel-p rograms-to-house-migrant-tide-from-u-s

\section{Opinion Articles.}

Coyne, A. (2017, February 21). A crisis is coming: If this many cross the U.S. border in February, how many will come by June? The National Post. Retrieved from https://nationalpost.com/opinion/a-crisis-is-coming-if-this-many-cross-the-u-s-border-in-februar y-how-many-will-come-by-june

Coyne, A. (2018, June 20). Andrew Coyne: Without the Safe Third Country Agreement, we'd soon see how liberal on refugees we really are. The National Post. Retrieved from https://nationalpost.com/opinion/andrew-coyne-without-the-safe-third-country-agreement-wed-s oon-see-how-liberal-on-refugees-we-really-are?video autoplay=true

Coyne, A. (2018, May 7). Andrew Coyne: Problem with asylum seekers in Canada can only be fixed if U.S. decides to help. The National Post. Retrieved from https://nationalpost.com/opinion/andrew-coyne-problem-with-asylum-seekers-in-canada-can-onl y-be-fixed-if-u-s-decides-to-help

Coyne, A. (2017, August 25). Andrew Coyne: Blame Trudeau? Blame Trump? Truth is there are no easy answers to asylum-seekers. The National Post. Retrieved from https://nationalpost.com/opinion/andrew-coyne-blame-trudeau-blame-trump-truth-is-there-are-no -easy-answers-to-asylum-seekers

Ivison, J. (2017, November 2). John Ivison: In the era of extreme immigration vetting, Canada remains a noble outlier. The National Post. Retrieved from https://nationalpost.com/opinion/john-ivison-in-the-era-of-extreme-immigration-vetting-canada-r emains-a-noble-outlier

Ivison, J. (2017, November 7). John Ivison: Liberals braced for another 'huge wave' of illegal asylum seekers from U.S. The National Post. Retrieved from https://nationalpost.com/opinion/john-ivison-liberals-brace-for-another-huge-wave-of-illegal-asy $\underline{\text { lum-seekers-from-u-s }}$

Ivison, J. (2018, May 4). John Ivison: Liberals turn a blind eye to border jumpers to keep Trump happy. The National Post. Retrieved from 
https://nationalpost.com/opinion/john-ivison-liberals-turn-a-blind-eye-to-border-jumpers-to-keep -trump-happy

Ivison, J. (2018, November 29). John Ivison: Budget officer finds illegal migrants entering via a 'loophole within a loophole'. The National Post. Retrieved from https://nationalpost.com/opinion/john-ivison-pbo-report-on-border-migration-puts-lie-to-liberal-c laim-the-system-is-working

McParland, K. (2017, February 23). Kelly McParland: If the Liberals drop the migrant ball, Canadians will lose patience quickly. The National Post. Retrieved from https://nationalpost.com/opinion/kelly-mcparland-if-the-liberals-drop-the-migrant-ball-canadians -will-lose-patience-quickly

McParland, K. (2018, June 28). Kelly McParland: Canada's border, the serious issue Ottawa's too busy to worry about. The National Post. Retrieved from https://nationalpost.com/opinion/kelly-mcparland-canadas-border-the-serious-issue-ottawas-toobusy-to-worry-about

McParland, K. (2018, July 12). Kelly McParland: Ford is telling Trudeau what needs to be said about the border. The National Post. Retrieved from https://nationalpost.com/opinion/kelly-mcparland-ford-is-telling-trudeau-what-needs-to-be-saidabout-the-border?video autoplay=true

Selley, C. (2017, February 17). Chris Selley: As Trump's refugees stream into Canada, will our immigration policies hold up? The National Post. Retrieved from https://nationalpost.com/opinion/chris-selley-as-trumps-refugees-stream-into-canada-will-our-im migration-policies-hold-up

Selley, C. (2017, August 23). Chris Selley: Astonishing nonsense from the Liberals amid surge of asylum-seekers. The National Post. Retrieved from https://nationalpost.com/opinion/chris-selley-astonishing-nonsense-from-the-liberals-on-surge-of -asylum-seekers

Selley, C. (2018, July 17). Chris Selley: Both Justin Trudeau and Doug Ford are handling border-crossers issue badly. The National Post. Retrieved from https://nationalpost.com/news/canada/chris-selley-both-justin-trudeau-and-doug-ford-are-handlin g-border-crossers-issue-badly

Selley, C. (2018, November 30). Chris Selley: Canada's fantasyland politics can't fix our refugee backlog. The National Post. Retrieved from https://nationalpost.com/opinion/chris-selley-canadas-fantasyland-politics-cant-fix-our-refugee-b acklog?video autoplay=true 


\section{Appendix B: Data Extraction Questions}

1. Where has the information in the article come from?

a. Who are the articles sources?

2. How much power and social influence do the cited/quoted sources have?

3. How much power and social influence does the focus, or subjects, of the story have?

4. Are asylum seekers indirectly or directly quoted?

5. What explicit and implicit meanings are conveyed by the words chosen to refer to people, places, concepts, events, or processes?

6. Is there a customary or habitually used constellation of representations associated with stories on this subject? Are these negative or positive?

7. Which of the following representational strategies are employed?

a. Personalization and impersonalization

b. Individualization versus collectivism

c. Specification and generalization

d. Nominalisation or functionalization

e. Use of honorifics

f. Objectification

g. Anonymization

h. Aggregation

i. "Us" and "them" division

j. Suppression 
8. Who, if anyone, is "othered" by the reporting? That is, whom does the report construct as "us" and who are "they"? Are any of "them" represented as part of "us" in other reporting contexts? What are the possible reasons behind this?

9. How does reporting relate to, or reflect, wider structural or social inequalities?

10. Is the theme of neoliberalism (how much money do they cost, how they don't bring in) present?

11. Is the theme of nationalism (threats to culture, way of life, systems, institutions) present?

12. Is the theme of moral panic present? (illegality, terrorism, criminality)

13. Does this article mention larger contexts motivating people to claim asylum? 


\section{References}

Abid, R., Manan, S.A., and Rahman, Z.A.A.A. (2017). 'A flood of Syrians has slowed to a trickle': The use of metaphors in the representation of Syrian refugees in the online media news reports of host and non-host countries. Discourse \& Communications, 11(2). 121-140.

DOI: $10.1177 / 1750481317691857$

Andrew-Gee, E. (2017, May 31). With asylum seeker's reported death, Canada-U.S. crossing debate intensifies. The Globe and Mail. Retrieved from https://www.theglobeandmail.com/news/national/with-asylum-seekers-reported-death-canada-us -crossing-debate-intensifies/article35171898/

Angus Reid Institute. (2018). Two-thirds call irregular border crossings a 'crisis,' more trust Scheer to handle issue than Trudeau. Retrieved from http://angusreid.org/safe-third-country-asylum-seekers

Arat-Koc, S. (2012). Invisibilized, individualized and culturalized: Paradoxical invisibility and hyper-visibility of gender in policy making and policy discourse in neoliberal Canada. Canadian Woman Studies 29(3): 6-17.

Ashutosh, I. and Mountz, A. (2012). The geopolitics of migrant mobility: Tracing state relations through refugee claims, boats, and discourses. Geopolitics, 17. 335-354.

DOI: $10.1080 / 14650045.2011 .567315$

Atak, I. (2018). Safe country of origin: Constructing the irregularity of asylum seekers in Canada. International Migration, 56(6). 176-190.

DOI: 10.1111 /imig. 12450

Behrman, S. (2014). Accidents, agency and asylum: Constructing the refugee subject. Law and Critique, 25. 249-270. DOI 10.1007/s10978-014-9140-x

Bell, S. (2017, March 8). Refugee claims in Canada could jump as Europe tightens borders: CBSA report. The National Post. Retrieved from https://nationalpost.com/news/canada/refugee-claims-in-canada-could-jump-as-europe-tightens-b orders-cbsa-report

Bender, M.C. (2019, February 15). How the border wall, Trump's signature campaign promise, turned into a national emergency. The Wall Street Journal. Retrieved from https://www.wsj.com/articles/trump-promised-to-build-that-wall-then-ran-out-of-time-and-optio $\underline{\text { ns-11550262854 }}$

Berry, M., Garcia-Blanco, I., Moore, K., Morani, M.; Gross, B., Askanius, T., and Linné, T. (2015). Press coverage of the refugee and migrant crisis in the EU: a content analysis of five European countries. United Nations High Commissioner for Refugees. Retrieved from http://www.unhcr.org/56bb369c9.html 
Blidook, K. (2009). Choice and Content: Media ownership and democratic ideals in Canada. The Canadian Political Science Review, 3(2). 52-69.

Cartner, J.M. (2009). Representing the refugee: Rhetoric, discourse and the public agenda (Doctoral dissertation, University of Notre Dame Australia). Retrieved from https://researchonline.nd.edu.au/theses/43

Cheong, P.H., R. Edwards, H. Goulbourne, and J. Solomos. (2007). Immigration, social cohesion and social capital: A critical review. Critical Social Policy, 27(1). 24-49.

Chepkemoi, J. (2019). The most popular daily newspapers in canada. Retrieved from https://www.worldatlas.com/articles/the-most-popular-daily-newspapers-in-canada.html

Clark, C. (2017, August 6). There's no easy solution to Canada's border problem. The Globe and Mail. Retrieved from https://www.theglobeandmail.com/opinion/theres-no-easy-solution-to-canadas-border-problem/a rticle35891673/

Clark, C. (2018, April 26). Declaring entire Canada-U.S. border an official entry point tops Trump's border wall idea for futility. The Globe and Mail. Retrieved from https://www.theglobeandmail.com/politics/article-declaring-entire-canada-us-border-an-officialentry-point-tops-trump/

Cohn, D., Passel, J.S., and Bialik, K. (2019). Many immigrants with Temporary Protected Status face uncertain future in U.S. Retrieved from https://www.pewresearch.org/fact-tank/2019/03/08/immigrants-temporary-protected-status-in-us/

Connolly, A. (2019, June 24). Irregular border crossings into Canada drop by half since same time last year. Global News. Retrieved from https://globalnews.ca/news/5425884/canada-irregular-border-crossings-decrease-by-half/

Coyne, A. (2017, April 26). Andrew Coyne: How should Canada respond to Trump? By doing things we ought to be doing anyway. The National Post. Retrieved from https://nationalpost.com/opinion/andrew-coyne-how-should-canada-respond-to-trump-by-doing-t hings-we-ought-to-be-doing-anyway

Coyne, A. (2018, May 7). Andrew Coyne: Problem with asylum seekers in Canada can only be fixed if U.S. decides to help. The National Post. Retrieved from https://nationalpost.com/opinion/andrew-coyne-problem-with-asylum-seekers-in-canada-can-onl y-be-fixed-if-u-s-decides-to-help

Curry, B. and Zilio, M. (2018, November 29). Ottawa on pace to spend more than \$1-billion over three years on unauthorized border crossings: watchdog. The Globe and Mail. Retrieved from https://www.theglobeandmail.com/politics/article-ottawa-on-pace-to-spend-400-million-next-yea r-on-border-crossings/ 
Dawson, G. (2018, May 27). Justin Trudeau's narcissism reveals Canada's divisions. The Conversation. Retrieved from https://theconversation.com/justin-trudeaus-narcissism-reveals-canadas-divisions-95767

Every, D. (2006). The politics of representation : the discursive analysis of refugee advocacy in the Australian parliament (Doctoral dissertation). Retrieved from http://hdl.handle.net/2440/37856

Fairclough, N. (2003). Analysing discourse: Textual analysis for social research. New York: Routledge.

Forrest, M. (2017a, September 28). More than 32,000 asylum seekers have arrived in Canada so far in 2017. The National Post. Retrieved from https://nationalpost.com/news/politics/more-than-32000-asylum-seekers-have-arrived-in-canada$\underline{\text { so-far-in-2017 }}$

Forrest, M. (2017b, August 23). 'Will Canada send people back?': Fate uncertain for asylum seekers arriving at tent city. The National Post. Retrieved from https://nationalpost.com/news/politics/will-canada-send-people-back-fate-uncertain-for-asylum-s eekers-arriving-at-tent-city

Forrest, M. (2018, November 22). Federal government has spent $\$ 2.3 \mathrm{M}$ to house asylum seekers in Toronto hotels, some rooms still booked until January. The National Post. Retrieved from

https://nationalpost.com/news/politics/federal-government-has-spent-2-3m-to-house-asylum-see kers-in-toronto-hotels-some-rooms-still-booked-until-january

Friesen, J. (2018, May 17). Hundreds of Canadian children held in immigration detention, report shows. The Globe and Mail. Retrieved from https://www.theglobeandmail.com/news/national/hundreds-of-canadian-children-held-in-immigr ation-detention-report-shows/article34117189/

Giovannetti, J. (2017a, February 24). Following the Midwest Passage: Asylum seekers take a cold journey to Manitoba via Trump's America. The Globe and Mail. Retrieved from https://www.theglobeandmail.com/news/national/influx-of-refugees-fleeing-us-are-putting-ottaw a-to-the-test/article34087595/

Giovannetti, J. (2017b, February 19). Influx of refugees fleeing U.S. is putting Ottawa to the test. The Globe and Mail. Retrieved from https://www.theglobeandmail.com/news/national/influx-of-refugees-fleeing-us-are-putting-ottaw a-to-the-test/article34087595/

Globe and Mail. (n.d.). Journalists. Retrieved from https://www.theglobeandmail.com/about/journalists/columnists/ 
Goldring, L., Berinstein, C., and Bernhard, J.K. (2009). Institutionalizing precarious migratory status in Canada. Citizenship Studies, 13(3). 239-265.

DOI: $10.1080 / 13621020902850643$

from

Government of Canada. (2016). Canada-U.S. Safe Third Country Agreement. Retrieved https://www.canada.ca/en/immigration-refugees-citizenship/corporate/mandate/policies-operatio nal-instructions-agreements/agreements/safe-third-country-agreement.html

Government of Canada. (2018). International perspective. Retrieved from https://www150.statcan.gc.ca/n1/pub/11-402-x/2011000/chap/geo/geo01-eng.htm

Government of Canada. (2019a). Asylum claims by year - 2018. Retrieved from https://www.canada.ca/en/immigration-refugees-citizenship/services/refugees/asylum-claims/asy lum-claims-2018.html

Government of Canada. (2019b). Asylum claims by year - 2017. Retrieved from https://www.canada.ca/en/immigration-refugees-citizenship/services/refugees/asylum-claims/asy $\underline{\text { lum-claims-2017.html }}$

Grant, T. (2018, June 20). Wave of asylum seekers floods Toronto's shelters. The Globe and Mail. Retrieved from https://www.theglobeandmail.com/canada/article-in-toronto-asylum-seekers-hope-to-carve-out-a -new-home/

Grant, T. (2018, August 1). Are asylum seekers crossing into Canada illegally? A look at facts behind the controversy. The Globe and Mail. Retrieved from https://www.theglobeandmail.com/canada/article-asylum-seekers-in-canada-has-become-a-divisi ve-and-confusing-issue-a/

Hall, S. (2018). The west and the rest: Discourse and power. In T. D. Gupta, C. E. James, C. Andersen, G. E. Galabuzi, and R. C. A. Maaka (Eds.), Race and Racialization: Essential Readings, Second Edition. (85-93). Toronto: Canadian Scholars.

Henry, F., and Tator, C. (2010). The colour of democracy (fourth edition): Racism in Canadian society (4th ed.). Canada: Nelson Education Ltd.

Hopper, T. (2018, July 10). Irregular or illegal? The fight over what to call the thousands of migrants streaming into Canada. The National Post. Retrieved from https://nationalpost.com/news/canada/irregular-or-illegal-the-fight-over-what-to-call-the-thousan ds-of-migrants-streaming-into-canada

Huot, S., Bobadilla, A., Bailliard, A., and Rudman, D. L. (2016). Constructing undesirables: A critical discourse analysis of 'othering' within the Protecting Canada's Immigration System Act. International Migration, 54(2): 131-143.

DOI: 10.1111/imig. 12210 
Hynie, M. (2018). Canada's Syrian refugee program, intergroup relationships and identities. Canadian Ethnic Studies, 50(2). 1-12. https://doi.org/10.1353/ces.2018.0012

Ibbitson (2018, June 29). Can one of the nicest places in the world - Canada - survive what's to come? The Globe and Mail. Retrieved from https://www.theglobeandmail.com/opinion/article-can-one-of-the-nicest-places-in-the-world-can ada-survive-whats-to/

Inouye, K. (2012). Conditional love; representations of migrant work in Canadian newsprint media. Social Identities, 18(5). 572-592. http://dx.doi.org/10.1080/13504630.2012.692895

International Organization for Migration (2011. Key migration terms. Retrieved from https://www.iom.int/key-migration-terms

Ivison, J. (2017, November 7). John Ivison: Liberals braced for another 'huge wave' of illegal asylum seekers from U.S. The National Post. Retrieved from https://nationalpost.com/opinion/john-ivison-liberals-brace-for-another-huge-wave-of-illegal-asy $\underline{\text { lum-seekers-from-u-s }}$

Ivision, J. (2018, May 4). John Ivison: Liberals turn a blind eye to border jumpers to keep Trump happy. The National Post. Retrieved from https://nationalpost.com/opinion/john-ivison-liberals-turn-a-blind-eye-to-border-jumpers-to-keep -trump-happy

Jørgensen, M, and Phillips, L. (2002). Discourse analysis as theory and method. London: Sage Publications.

Kaiser Ortiz, J. (2019). Jewels and Ladders: Visualizing and resisting the racialization and dehumanization of e/im-migrants and refugees. Critical Philosophy of Race, 7(1). 187-211. DOI: $10.5325 /$ critphilrace.7.1.0187

KhosraviNik, M. (2010). The representation of refugees, asylum seekers, and immigrants in British newspapers: A critical discourse analysis. Journal of Language and Politics, 9(1). $1-28$.

DOI: $10.1075 / \mathrm{jlp} \cdot 9.1 .01 \mathrm{kho}$

Kyriakides, C., Bajjali, L., McLuhan, A., and Anderson, K. (2018) Beyond refuge: Contested orientalism and persons of self-rescue. Canadian Ethnic Studies, 50(2). 59-78. https://doi.org/10.1353/ces.2018.0015

Lawlor, A. and Tolley, E. (2017). Deciding who's legitimate: News media framing of immigrants and refugees. International Journal of Communication 11. 967-991.

Lueck, K., Due, C., and Augoustinos, M. (2015). Neoliberalism and nationalism: Representations of asylum seekers in the Australian mainstream news media. Discourse \& 
Society, 25(5). 608-629.

DOI: $10.1177 / 0957926515581159$

Machin, D. and Mayr, A. (2012). How to do critical discourse analysis: A multimodal introduction. SAGE Publications. Retrieved from https://ebookcentral-proquest-com.ezproxy.lib.ryerson.ca/lib/ryerson/detail.action?docID=88080 $\underline{3}$

Markusoff, J. (2018, January 10). Canada's failing refugee system is leaving thousands in limbo. Maclean's. Retrieved from https://www.macleans.ca/news/canada/canadas-refugee-system-is-in-chaos/

Mason, G. (2018, July 10). Migrants dying at sea used to spark outrage. So what's changed? The Globe and Mail. Retrieved from https://www.theglobeandmail.com/opinion/article-will-europes-migrant-backlash-spread-here/

McGregor, S.L.T. (2010). Critical discourse analysis: A primer. Critical Science and Critical Discourse Analysis, 15(1). Retrieved from https://www.kon.org/archives/forum/15-1/mcgregorcda.html

McParland, K. (2018, June 28). Kelly McParland: Canada's border, the serious issue Ottawa's too busy to worry about. The National Post. Retrieved from https://nationalpost.com/opinion/kelly-mcparland-canadas-border-the-serious-issue-ottawas-toobusy-to-worry-about

Meyer, M. (2017). Canada's top 20 daily newspapers. Retrieved from https://www.cision.ca/trends/canadas-top-20-daily-newspapers/

Missirian, A. and Schlenker, W. (2017). Asylum applications respond to temperature fluctuations. Science, 358(6370): 1610-1614. DOI: 10.1126/science.aao0432

Mogashoa, T. (2014). Understanding critical discourse analysis in qualitative research. International Journal of Humanities Social Sciences and Education, 1(7). 104-113.

Nail, T. (2015). The figure of the migrant. Stanford: Stanford University Press.

Nimijean, R. (2017). A portrait of Justin Trudeau. Retrieved from https://www.policyalternatives.ca/publications/monitor/portrait-justin-trudeau

Perreaux, L. (2017a, December 22). Fatigue may have played role in crash that killed Quebec Mountie during border crossings surge. The Globe and Mail. Retrieved from https://www.theglobeandmail.com/news/national/fatigue-may-have-played-role-in-crash-that-kill ed-quebec-mountie-during-asylum-surge/article37418281/

Perreaux, L. (2017b, August 3). Quebec's resources wear thin as wave of asylum seekers swells. The Globe and Mail. Retrieved from https://www.theglobeandmail.com/news/national/quebec-dealing-with-150-asylum-requests-a-da y-immigration-minister/article35871581/ 
Philo, G., Brian, E., and Donald, P. (2013). Bad news for refugees. London: Pluto Press.

Pierce, S. and Selee, A. (2017). Immigration under Trump: A review of policy shifts in the year since the election. Migration Policy Institute. Retrieved from https://www.migrationpolicy.org/research/immigration-under-trump-review-policy-shifts

Porter, E. and Russell, K. (2018, June 20). Migrants are on the rise around the world, and myths about them are shaping attitudes. The New York Times. Retrieved from https://www.nytimes.com/interactive/2018/06/20/business/economy/immigration-economic-imp act.html.

Quan, D. (2017, February 7). Manitoba town's generosity is tested amid spike in asylum-seeking 'border jumpers' since Trump elected. The National Post. Retrieved from https://nationalpost.com/news/canada/worried-about-trump-asylum-seekers-braving-the-freezing -prairie-winter-to-walk-into-canada

Reisigl, M. and Wodak, R. (2001). Discourse and discrimination: Rhetorics of racism and antisemitism. London: Routledge.

Richardson, J.E. (2007). Analysing newspapers: an approach from critical discourse analysis. New York: Palgrave MacMillan.

Root, J., Gates-Gasse, E., Shields, J., and Bauder, H. (2014). Discounting Immigrant families: Neoliberalism and the framing of Canadian immigration policy change. RCIS Working Paper, 7. 1-23. Retrieved from https://www.ryerson.ca/content/dam/rcis/RCIS-WP-Root-No2014-7.pdf

Selley, C. (2017a, February 17). Chris Selley: As Trump's refugees stream into Canada, will our immigration policies hold up? The National Post. Retrieved from https://nationalpost.com/opinion/chris-selley-as-trumps-refugees-stream-into-canada-will-our-im migration-policies-hold-up

Sheth, F. A. (2009). Toward a political philosophy of Race. Albany: SUNY Press.

Smith, M.D. (2018, April 3). Trudeau tweet caused influx of refugee inquiries, confusion within government, emails reveal. The National Post. Retrieved from https://nationalpost.com/news/politics/trudeau-tweet-caused-influx-of-refugee-inquiries-confusio n-within-government-emails-reveal

Statistics Canada. (2019). Just the facts: Asylum claimants. Retrieved from https://www150.statcan.gc.ca/n1/pub/89-28-0001/2018001/article/00013-eng.htm.

Statistics Times. (2019). List of countries by projected GDP. Retrieved from http://statisticstimes.com/economy/countries-by-projected-gdp.php 
Steinberg, P.E., Page, S., Dittmer, J., Gökariksel, B. Smith, S., Ingram, A., and Koch, N. (2018). Reassessing the Trump presidency, one year on. Political Geography, 62. 207-215. https://doi.org/10.1016/j.polgeo.2017.10.010

Steuter, E. and Wills, D. (2009). Discourses of dehumanization: enemy construction and Canadian media complicity in the framing of war on terror. Global Media Journal, 2(2), 7-24. DOI?

Stevenson, V. (2017, August 18). What refugee claimants receive from the government. CBC News. Retrieved from https://www.cbc.ca/news/canada/montreal/asylum-seekers-support-housing-1.4252114

Sutherland, C. and Roszko, E. (2015). Introduction: Nationalism in Southeast Asia. Nations and Nationalism, 21(2). 203-208. DOI: 10.1111/nana.12093

The Globe and Mail. (2017, February 21). Globe editorial: Is Canada ready for Donald Trump's refugee crisis? The Globe and Mail. Retrieved from https://www.theglobeandmail.com/opinion/editorials/globe-editorial-is-canada-ready-for-donaldtrumps-refugee-crisis/article34104802/

thor Straten, J. E. (2016). Who are these 'refugees'?. (Doctoral dissertation, Malmö University). Retrieved from https://pdfs.semanticscholar.org/4cb4/7d58c10b2563b59aa6bf43f273ff90a2506b.pdf

Tolley, E. (2016). Framed: Media and the coverage of race in Canadian politics. Vancouver: UBC Press.

Torkington, K. and Ribeiro, F.P. 'What are these people: migrants, immigrants, refugees?': Migration-related terminology and representations in Portuguese digital press headlines. Discourse, Context \& Media, 27. 22-31. https://doi.org/10.1016/j.dcm.2018.03.002

Tyyskä, V., Blower, J., DeBoer, S., Kawai, S., and Walcott, A. (2018). Canadian media coverage of the Syrian refugee crisis: Representation, response, and resettlement. Geopolitics, History, and International Relations, 10(1), 148-166.

DOI: $10.22381 /$ GHIR10120187

United Nations High Commissioner for Refugees. (2006). The global report 2005. Retrieved from https://www.unhcr.org/publications/fundraising/4a0c04f96/global-report-2005.html

United Nations High Commissioner for Refugees. (2010). Convention and protocol relating to the status of refugees. Retrieved from https://www.unhcr.org/3b66c2aa10

United Nations High Commissioner for Refugees. (2018). Global trends: Forced displacement in 2017. Retrieved from https://www.unhcr.org/5b27be547.pdf 
United Nations High Commissioner for Refugees. (2019a). Global trends: Forced displacement in 2018. Retrieved from https://www.unher.org/statistics/unhcrstats/5d08d7ee7/unher-global-trends-2018.html

United Nations High Commissioner for Refugees. (2019b). Refugees and migrants from Venezuela top 4 million: UNHCR and IOM. Retrieved from https://www.unhcr.org/news/press/2019/6/5cfa2a4a4/refugees-migrants-venezuela-top-4-millionunhor-iom.html

Van der Valk, I. (2003). Right-wing parliamentary discourse on immigration in France. Discourse and Society, 14(3). 309-348. https://doi.org/10.1177/0957926503014003084 $17-27$.

van Dijk, T.A. (1995). Aims of critical discourse analysis. Japanese Discourse, 1(1),

van Dijk, T.A. (2000). New(s) racism: a discourse analytical approach. In Cottle, S. (Ed.), Ethnic Minorities and the Media. Open University Press. 33-49.

van Leeuwan, T. (2008). Discourse and practice: New tools for critical discourse analysis. New York: Oxford University Press.

Van Zandt, D. (2018). The Globe and Mail. Retrieved from https://mediabiasfactcheck.com/the-globe-and-mail/

Van Zandt, D. (2019). The National Post. Retrieved from https://mediabiasfactcheck.com/national-post/

von Scheel, E. (2019, June 1). Some believe U.S. no safe haven for asylum seekers, despite Canada's Third Country Agreement. CBC News. Retrieved from https://www.cbc.ca/news/politics/u-s-immigration-asylum-border-canada-safe-von-scheel-1.515 $\underline{6288}$

Warnica, R. (2018, June 26) Toronto faces having to close community centres, cancel programs to house migrant tide from U.S. The National Post. Retrieved from https://nationalpost.com/news/canada/toronto-faces-having-to-close-community-centres-cancel-p rograms-to-house-migrant-tide-from-u-s

Wente, M. (2018, August 23). Another summer, another border crisis. The Globe and Mail. Retrieved from https://www.theglobeandmail.com/opinion/article-another-summer-another-border-crisis/

Wodak, R. (2001). What CDA is about: A summary of its history, important concepts, and its developments. In R. Wodak and M. Meyer (Eds.), Methods of Critical Discourse Analysis. (1-13). London: Sage.

Woods, A. (2017, February 10). Is Trump's refugee crackdown threat pushing asylum seekers into Canada? The Toronto Star. Retrieved from 
https://www.thestar.com/news/canada/2017/02/10/is-trumps-refugee-crackdown-threat-pushingasylum-seekers-into-canada.html

Yakabuski, Y. (2018, August 22). Something's rotten in Canadian politics. The Globe and Mail. Retrieved from https://www.theglobeandmail.com/opinion/article-somethings-rotten-in-canadian-politics/

Zilio, M. (2019, April 1). Canada, U.S. move to redraft border treaty to cut flow of asylum seekers. The Globe and Mail. Retrieved from

https://www.theglobeandmail.com/politics/article-us-moves-to-open-talks-with-canada-on-asylu m-seeker-treaty/

Zimonjic, P. (2018, May 7). Fewer than 1\% of more than 28,000 irregular asylum seekers have been removed from Canada so far. CBC News. Retrieved from https://www.cbc.ca/news/politics/immigration-removals-asylum-seekers-1.465272 